\title{
HIGH-CURRENT-DENSITY ELECTROPOLISHING (HDEP) OF AISI 316L (EN 1.4404) STAINLESS STEEL
}

\author{
Krzysztof Rokosz, Tadeusz Hryniewicz, Stawomir Rzadkiewicz, Steiner Raaen
}

Original scientific paper

The paper presents new XPS results of surface layers formed after electrochemical polishing of AISI 316L stainless steel at high current density (HDEP) of $1000 \mathrm{~A} / \mathrm{dm}^{2}$ (EP1000) versus a standard electropolishing (EP50) process used in the industry, i.e. at $50 \mathrm{~A} / \mathrm{dm}^{2}$. For the investigation, different compositions of electrolytes, based on orthophosphoric and sulfuric acids in proportions 4:6, 6:4, 1:0, respectively, were used. The obtained results have clearly shown that both the solution composition and current density highly influence the structure and compositions of passive layers formed after electrochemical treatments. For the steel used as a biomaterial, the surface films with a minimum amount of carcinogenic nickel was found; here also a maximum $(\mathrm{Cr}+3.3 \cdot \mathrm{Mo}) / \mathrm{Fe}$ coefficient was noticed. On the basis of the obtained results it can be concluded that for $316 \mathrm{~L}$ SS used as a biomaterial, the electrochemical treatments EP50 and EP1000 in $40 \mathrm{vol} \% \mathrm{H}_{3} \mathrm{PO}_{4}$ and $60 \mathrm{vol} \% \mathrm{H}_{2} \mathrm{SO}_{4}$ solution as well as EP50 in 60 vol\% $\mathrm{H}_{3} \mathrm{PO}_{4}$ and 40 vol\% $\mathrm{H}_{2} \mathrm{SO}_{4}$ solution, should be used. In case of 316L SS not to be used for implants in the human body, EP1000 in pure concentrated orthophosphoric acid, is advised. EP1000 treatment of the $316 \mathrm{~L} \mathrm{SS}$ in $60 \mathrm{vol} \% \mathrm{H}_{3} \mathrm{PO}_{4}$ and $40 \mathrm{vol} \% \mathrm{H}_{2} \mathrm{SO}_{4}$ electrolyte may be used in case of applying the biomaterial for a non-Ni-allergic patient.

Keywords: biomaterials; corrosion; electropolishing; electrochemical techniques; surface properties; X-ray photo-emission spectroscopy (XPS)

\section{Elektrolitičko poliranje nehrđajućeg čelika AISI 316L (EN 1.4404) uz visoku gustoću struje (HDEP)}

Izvorni znanstveni članak

U radu se predstavljaju novi XPS rezultati površinskih slojeva dobivenih nakon elektrokemijskog poliranja nehrđajućeg čelika AISI 316L uz visoku gustoću struje (HDEP) od $1000 \mathrm{~A} / \mathrm{dm}^{2}$ (EP1000) u odnosu na postupak standardnog elektrolitičkog poliranja (EP50) primijenjenog u industriji, t.j. kod 50 $\mathrm{A} / \mathrm{dm}^{2}$. U ispitivanju su rabljeni različiti sastavi elektrolita, temeljeni na fosfornim i sumpornim kiselinama u omjerima 4:6, 6:4, 1:0. Rezultati jasno pokazuju da i sastav otopine i gustoća struje imaju velikog utjecaja na strukturu i sastav pasivnih slojeva nastalih nakon elektrokemijske obrade. Za čelik koji se koristi kao biomaterijal ustanovljeni su površinski slojevi s minimalnom količinom karcinogenog nikla; tu je također primijećen maksimalan $(\mathrm{Cr}+3,3 \cdot \mathrm{Mo}) / \mathrm{Fe}$ koeficijent. Na temelju dobivenih rezultata može se zaključiti da bi se za 316L SS, kad se rabi kao biomaterijal, trebale primijeniti elektrokemijske obrade EP50 i EP1000 u 40 vol\% $\mathrm{H}_{3} \mathrm{PO}_{4}$ i otopini 60 vol\% $\mathrm{H}_{2} \mathrm{SO}_{4}$ kao i EP50 u 60 vol\% $\mathrm{H}_{3} \mathrm{PO}_{4}$ i otopini 40 vol\% $\mathrm{H}_{2} \mathrm{SO}_{4}$. Kada se $316 \mathrm{~L}$ SS ne planira koristiti za implantate u ljudskom tijelu, preporučuje se EP1000 u čistoj koncentriranoj fosfornoj kiselini. Postupak obrade EP1000 nehrđajućeg čelika 316 u 60 vol\% $\mathrm{H}_{3} \mathrm{PO}_{4}$ i 40 vol\% elektrolitu $\mathrm{H}_{2} \mathrm{SO}_{4}$ može se koristiti kod primjene tog biomaterijala na pacijentu koji nije alergičan na Ni.

Ključne riječi: biomaterijali; elektrokemijske metode; elektrolitičko poliranje; fotoemisijska spektroskopija rendgenskim zrakama (XPS); korozija; površinska svojstva;

\section{Introduction}

Nowadays austenitic stainless steels are increasingly used in many sorts of industries such as chemical, pharmaceutical, paper, textile industry, civil engineering as well as for biomaterials and petroleum refining equipment [1]. AISI 316L /EN 1.4404/ is molybdenumbearing austenitic stainless steel. It contains more nickel $(10 \div 14 \%)$ and less chromium $(16 \div 18 \%)$ than more popular AISI $304 \mathrm{~L} / 1.4307 /(8 \div 10,5 \%$ nickel, $18 \div 20$ $\%$ chromium) and additional $2 \div 3 \%$ molybdenum. Due to the chemical composition the steel has good corrosion resistance (general and pitting) in many aggressive environments. Moreover, after electrochemical treatments, mechanical $[2,3]$ and electrochemical $[3 \div 6]$ properties as well as chemical composition $[7 \div 16]$ of the surface layer of stainless steel undergo changes. The addition of molybdenum improves pitting and crevice corrosion resistance in chloride media as well as in sulfuric, phosphoric and acetic acids environments [17]. Furthermore, it has a high creep resistance, excellent formability, rupture and tensile strength at high temperatures. In cookware, cutlery, hardware, surgical instruments, major appliances, industrial equipment, and building material in skyscrapers and large buildings the steel can be used. For electrochemical polishing nowadays in the industry there is most often used electrolyte on the basis of sulfuric acid $\mathrm{H}_{2} \mathrm{SO}_{4}$ and phosphoric acid $\mathrm{H}_{3} \mathrm{PO}_{4}$ with addition of water as well as with surface active agents or inhibitors of digestion. In Tab. 1 there are listed available in the literature electrolyte compositions with additional information regarding current density and temperature of the electro-treatment.

The aim of the paper was to show differences in surface layers after electrochemical polishing due to high current density $\left(1000 \mathrm{~A} / \mathrm{dm}^{2}\right)$ and electrolyte composition. Authors have not found in the available literature any detailed information about the surface layers formed on AISI 316L austenitic stainless steel at current densities close to $1000 \mathrm{~A} / \mathrm{dm}^{2}$. The research has scientific aspects such as XPS data collection for specific steels, here AISI $316 \mathrm{~L}$ and in suitable electrolytes. On the other hand the utility aspect should also be highlighted. Nowadays the finishing treatment of coronary stents by electrochemical polishing is one of the most important aspects of biomaterial production. Due to the fact that the dimensions of the stents are small, the high current densities (about $1000 \mathrm{~A} / \mathrm{dm}^{2}$ ) are possible to be achieved on generally available in trade current sources. The main goal of the paper is to show the possibilities of completely changing the chemical composition of passive layer on the basis of only the change of current density or/and the phosphoric acid to sulfuric acid volume ratio. 
Table 1 Electropolishing electrolyte types with the process conditions \begin{tabular}{|l|c|c|c|}
\hline ELECTROLYTE COMPOSITION & $i / \mathrm{A} / \mathrm{dm}^{2}$ & $T /{ }^{\circ} \mathrm{C}$ & Ref.
\end{tabular}

\begin{tabular}{|c|c|c|c|}
\hline $\begin{array}{c}40 \div 80 w_{t} \% \mathrm{H}_{3} \mathrm{PO}_{4}+50 \div 70 \mathrm{wt} \% \\
\mathrm{H}_{2} \mathrm{SO}_{4}+10 \div 30 \mathrm{wt} \% \mathrm{H}_{2} \mathrm{O}\end{array}$ & 5 & $30 \div 80$ & {$[18 \div 21]$} \\
\hline $\mathrm{H}_{3} \mathrm{PO}_{4}+\mathrm{H}_{2} \mathrm{CrO}_{4}$ & $10 \div 100$ & $30 \div 80$ & \\
\hline $\mathrm{H}_{2} \mathrm{SO}_{4}+\mathrm{C}_{6} \mathrm{H}_{8} \mathrm{O}_{7} \cdot \mathrm{xH}_{2} \mathrm{O}$ & 10 & 95 & \multirow{3}{*}[22]{} \\
\hline $\mathrm{H}_{3} \mathrm{PO}_{4}+\mathrm{C}_{3} \mathrm{H}_{8} \mathrm{O}_{3}$ & 2 & 95 & \\
\hline $\mathrm{H}_{2} \mathrm{SO}_{4}+\mathrm{C}_{2} \mathrm{H}_{4} \mathrm{O}_{3}$ & 15 & $80 \div 100$ & \\
\hline \begin{tabular}{|c|}
55,4 vol. $\% \mathrm{H}_{3} \mathrm{PO}_{4}+44,4$ vol. $\%$ \\
$\mathrm{H}_{2} \mathrm{SO}_{4}+0,2$ vol. $\% \mathrm{~N}\left(\mathrm{CH}_{2} \mathrm{CH}_{2} \mathrm{OH}\right)_{3}$
\end{tabular} & $40 \div 50$ & $60 \div 65$ & \multirow{2}{*}{ [23] } \\
\hline $\begin{array}{c}45,5 \text { vol. } \% \mathrm{H}_{3} \mathrm{PO}_{4}+55,5 \text { vol. } \% \\
\mathrm{H}_{2} \mathrm{SO}_{4}+8 \div 10 \mathrm{~g} \mathrm{C}_{2} \mathrm{H}_{5} \mathrm{NO}_{2}\end{array}$ & $80 \div 140$ & $85 \div 95$ & \\
\hline $\begin{aligned} 43 \mathrm{wt} \% & \mathrm{H}_{3} \mathrm{PO}_{4}+15 \mathrm{wt}^{\circ} \% \mathrm{H}_{2} \mathrm{SO}_{4} \\
& +42 \mathrm{wt} \% \mathrm{H}_{2} \mathrm{O}\end{aligned}$ & $i>5$ & $40 \div 60$ & \multirow{3}{*}[24\div27]{} \\
\hline $\begin{aligned} & 56 \mathrm{wt} \% \mathrm{H}_{3} \mathrm{PO}_{4}+32 \mathrm{wt} \% \mathrm{H}_{2} \mathrm{SO}_{4} \\
&+12 \mathrm{wt} \% \mathrm{CrO}_{3} \\
&\end{aligned}$ & $10 \div 100$ & $40 \div 80$ & \\
\hline $\begin{array}{c}60 \mathrm{wt} \% \mathrm{H}_{3} \mathrm{PO}_{4}+37 \mathrm{wt}^{2} \mathrm{H}_{2} \mathrm{SO}_{4}+ \\
3 \mathrm{wt} \% \mathrm{H}_{2} \mathrm{O}+\mathrm{C}_{3} \mathrm{H}_{6} \mathrm{O}_{3} \\
\text { (additional } 20 \div 22 \mathrm{ml} \text { per liter of } \\
\text { solution) }\end{array}$ & 80 & $50 \div 80$ & \\
\hline $\mathrm{H}_{3} \mathrm{PO}_{4}>\mathrm{H}_{2} \mathrm{SO}_{4}+25$ vol. $\% \mathrm{H}_{2} \mathrm{O}$ & $20 \div 70$ & $30 \div 70$ & [28] \\
\hline $\begin{array}{c}\mathrm{H}_{3} \mathrm{PO}_{4}: \mathrm{H}_{2} \mathrm{SO}_{4}=1: 1 ; 2: 3 ; 3: 7 \\
\text { (additional } 0 \div 30 \% \mathrm{H}_{2} \mathrm{O} \text { and } 0 \div 10 \\
\quad \% \mathrm{C}_{3} \mathrm{H}_{8} \mathrm{O}_{3} \text { by vol.) }\end{array}$ & $50 \div 300$ & $50 \div 90$ & {$[29,30]$} \\
\hline $\mathrm{H}_{3} \mathrm{PO}_{4}: \mathrm{H}_{2} \mathrm{SO}_{4}=1: 1 ; 1: 2 ; 1: 3$ & - & $6 \div 80$ & [31] \\
\hline $\begin{array}{c}42 \mathrm{wt} \% \mathrm{H}_{3} \mathrm{PO}_{4}+47 \mathrm{wt}^{2} \% \mathrm{C}_{3} \mathrm{H}_{8} \mathrm{O}_{3} \\
+11 \mathrm{wt} \% \mathrm{H}_{2} \mathrm{O}\end{array}$ & 130 & $90 \div 95$ & [32] \\
\hline $\begin{array}{c}195 \mathrm{ml} \mathrm{H}_{3} \mathrm{PO}_{4}+75 \mathrm{ml} \mathrm{H}_{2} \mathrm{SO}_{4}+30 \\
\mathrm{ml} \mathrm{H}_{2} \mathrm{O} \text { (additional } 0,75 \mathrm{~g} \\
\left.\mathrm{Na}_{5} \mathrm{P}_{3} \mathrm{O}_{10}\right) \\
\end{array}$ & $\begin{array}{c}78 \div 98^{(1)} \\
82 \div 112^{(2)}\end{array}$ & $\begin{array}{l}40^{(1)} \\
75^{(2)}\end{array}$ & {$[33,34]$} \\
\hline $\begin{array}{c}\mathrm{H}_{3} \mathrm{PO}_{4}: \mathrm{H}_{2} \mathrm{SO}_{4}=3: 2+10 \text { vol.\% } \\
\mathrm{H}_{2} \mathrm{O} \text { of total acids vol. } \\
\text { (additional } 20 \mathrm{~g} \mathrm{CrO}_{3} \text { per liter of } \\
\text { solution) }\end{array}$ & $55 \div 65$ & $60 \div 70$ & [3] \\
\hline $\begin{array}{c}875 \mathrm{~g} / \mathrm{cm}^{3} \mathrm{H}_{3} \mathrm{PO}_{4} 700 \mathrm{~g} / \mathrm{cm}^{3} \mathrm{H}_{2} \mathrm{SO}_{4} \\
+3 \mathrm{~g} / \mathrm{cm}^{3} \mathrm{~N}\left(\mathrm{CH}_{2} \mathrm{CH}_{2} \mathrm{OH}\right)_{3} \\
\end{array}$ & $40 \div 50$ & $60 \div 65$ & \multirow{2}{*}{ [35] } \\
\hline $\begin{array}{c}55,5 \mathrm{wt} \% \mathrm{H}_{3} \mathrm{PO}_{4}+45,5 \mathrm{wt} \% \\
\mathrm{H}_{2} \mathrm{SO}_{4}+8 \div 10 \mathrm{~g} / \mathrm{cm}^{3} \mathrm{C}_{2} \mathrm{H}_{5} \mathrm{NO}_{2}\end{array}$ & $80 \div 140$ & $85 \div 95$ & \\
\hline
\end{tabular}

AISI 304; ${ }^{(2)}$ AISI 316L

\section{Method}

\subsection{Material}

The AISI 316L (EN 1.4404) stainless steel samples served for the study, with the material composition presented in Tab. 2. The samples were cut off a coldrolled metal sheet of the stainless steel after plate rolling so that the austenitic structure was retained. They were prepared in the form of rectangular specimens of dimensions $30 \times 5 \mathrm{~mm}$ cut of the metal sheet $1 \mathrm{~mm}$ thick.

Table 2 Composition of AISI 316L SS, in wt $\%$

\begin{tabular}{|c|c|c|c|c|c|c|c|c|}
\hline $\mathrm{C}$ & $\mathrm{Cr}$ & $\mathrm{Mo}$ & $\mathrm{Ni}$ & $\mathrm{P}$ & $\mathrm{S}$ & $\mathrm{Mn}$ & $\mathrm{Si}$ & $\mathrm{Cu}$ \\
\hline 0,02 & 16,92 & 2,01 & 10,38 & 0,032 & 0,011 & 1,3 & 0,39 & 0,28 \\
\hline $\mathrm{Co}$ & $\mathrm{V}$ & $\mathrm{W}$ & $\mathrm{B}$ & $\mathrm{Al}$ & $\mathrm{Sn}$ & $\mathrm{N}_{2}$ & \multicolumn{2}{|c|}{$\mathrm{Fe}$} \\
\hline 0,19 & 0,09 & 0,04 & 0,0019 & 0,007 & 0,014 & 0,0405 & balance \\
\hline
\end{tabular}

\subsection{Set-up and parameters}

The electrolytic polishing operations were performed at the current density of $1000 \pm 10 \mathrm{~A} / \mathrm{dm}^{2}$. The main elements of the High Current Density Electropolishing (HDEP) set-up were: a processing cell, a dc power supply Telzas PDN 24-48-(60)/30(25), the electrodes and connecting wiring. The studies were carried out in the electrolyte of initial temperature of $20 \pm 2{ }^{\circ} \mathrm{C}$, with the temperature control of $\pm 5{ }^{\circ} \mathrm{C}$. Generally the final electrolyte temperature was $75 \pm 5{ }^{\circ} \mathrm{C}$. For the studies, a mixture of sulfuric/orthophosphoric acids electrolytes in the following proportions $\mathrm{H}_{3} \mathrm{PO}_{4}: \mathrm{H}_{2} \mathrm{SO}_{4} \in\{2: 3 ; 3: 2 ; 1: 0\}$ were used. For each run, the electrolytic cell made of glass was used, containing up to $500 \mathrm{~cm}^{3}$ of electrolyte solution. Additional $316 \mathrm{~L}$ SS samples treated by a standard electropolishing EP at the current density of $50 \pm 2 \mathrm{~A} / \mathrm{dm}^{2}$ were used for a reference; they were prepared in the same solutions as the previous treatments at proportions $\mathrm{H}_{3} \mathrm{PO}_{4}: \mathrm{H}_{2} \mathrm{SO}_{4}=3: 2, \mathrm{H}_{3} \mathrm{PO}_{4}: \mathrm{H}_{2} \mathrm{SO}_{4}=2: 3$, and pure concentrated $\mathrm{H}_{3} \mathrm{PO}_{4}$ and $\mathrm{H}_{2} \mathrm{SO}_{4}$ at temperature of $65 \pm 5^{\circ} \mathrm{C}$.

\subsection{XPS studies}

The XPS measurements on HDEP $\left(1000 \mathrm{~A} / \mathrm{dm}^{2}\right)$ electrochemically polished AISI $316 \mathrm{~L}$ stainless steel samples were performed using SCIENCE SES 2002 instrument using a monochromatic (Gammadata-Scienta) Al K(alpha) $(h v=1486.6 \mathrm{eV}) \mathrm{X}$-ray source $(18,7 \mathrm{~mA}$, $13,02 \mathrm{kV})$. Scans analyses were carried out with an analysis area of $3 \times 1 \mathrm{~mm}$ and a pass energy of $500 \mathrm{eV}$ with energy step $0,2 \mathrm{eV}$ and the step time $200 \mathrm{~ms}$. The binding energy of the spectrometer has been calibrated by the position of the Fermi level on a clean metallic sample. The power supplies were stable and of high accuracy. The experiments were carried out in an ultra-high-vacuum system with a base pressure of about $6 \times 10^{-10} \mathrm{~Pa}$. The XPS spectra were recorded in normal emission. In view of optimizing the signal-to-noise ratio to about 5,5, one XPS measurement cycle covered 30 sweeps. For the XPS analyses the CasaXPS 2.3.14 software with Shirley type background setup was used.

\section{Results}

In Fig. 1 and Fig. 2 there are shown the XPS spectra of iron ( $\mathrm{Fe} 2 \mathrm{p}$ ) and chromium ( $\mathrm{Cr} 2 \mathrm{p}$ ), respectively. In case of the iron spectra it is visible that the surface layer of sample, as received (black dotted), has the highest amounts of iron as metal as well as its compounds. In descending order of iron amounts are visible surface layers after electropolishing in: pure concentrated $\mathrm{H}_{3} \mathrm{PO}_{4}$ $\left(i=50 \mathrm{~A} / \mathrm{dm}^{2}\right), 40$ vol. $\% \mathrm{H}_{3} \mathrm{PO}_{4} \& 60$ vol. $\% \mathrm{H}_{2} \mathrm{SO}_{4}(i=50$ $\left.\mathrm{A} / \mathrm{dm}^{2}\right), 40$ vol. $\% \mathrm{H}_{3} \mathrm{PO}_{4} \& 60$ vol. $\% \mathrm{H}_{2} \mathrm{SO}_{4}(i=1000$ $\left.\mathrm{A} / \mathrm{dm}^{2}\right), 60$ vol.\% $\mathrm{H}_{3} \mathrm{PO}_{4} \& 40$ vol.\% $\mathrm{H}_{2} \mathrm{SO}_{4}(i=50$ $\left.\mathrm{A} / \mathrm{dm}^{2}\right), \mathrm{H}_{3} \mathrm{PO}_{4}\left(i=1000 \mathrm{~A} / \mathrm{dm}^{2}\right), 60$ vol.\% $\mathrm{H}_{3} \mathrm{PO}_{4} \& 40$ vol. $\% \mathrm{H}_{2} \mathrm{SO}_{4}\left(i=1000 \mathrm{~A} / \mathrm{dm}^{2}\right)$. In case of chromium spectra the differences are not so big. Minimum chromium amounts are visible for electropolishing (HDEP) in $60 \% \mathrm{H}_{3} \mathrm{PO}_{4} \& 40 \% \mathrm{H}_{2} \mathrm{SO}_{4}\left(i=1000 \mathrm{~A} / \mathrm{dm}^{2}\right)$ and maximum - for 40 vol\% $\mathrm{H}_{3} \mathrm{PO}_{4} \& 60 \mathrm{vol} \% \mathrm{H}_{2} \mathrm{SO}_{4}(i$ $=50 \mathrm{~A} / \mathrm{dm}^{2}$ ).

The analysis of molybdenum spectra is shown in Fig. 3. Most of molybdenum was detected in the form of compounds where it is on the sixth state of Mo oxidation. Lower contents of molybdenum oxide state levels in descending order were: fifth, fourth, third, second. The XPS signal of molybdenum as a metal was on the noise level. In the case of 30 sweeps performed it should be considered lack thereof. 


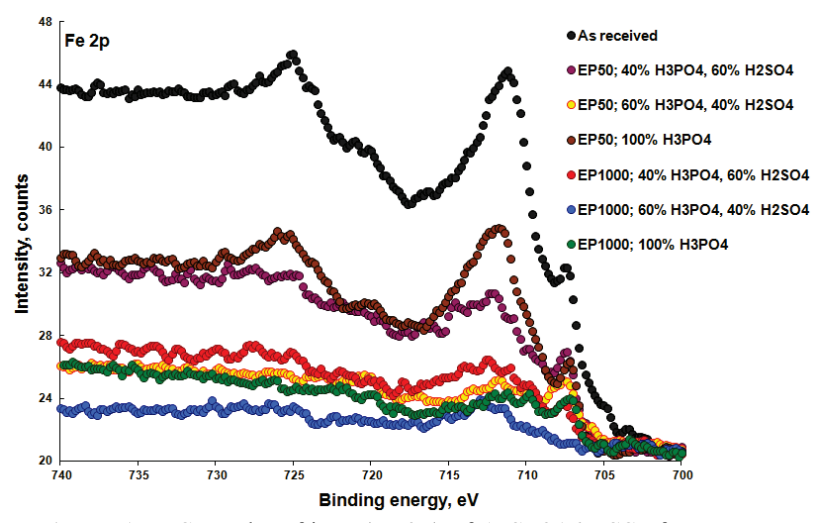

Figure 1 XPS results of iron (Fe 2p) of AISI 316L SS after HDEP

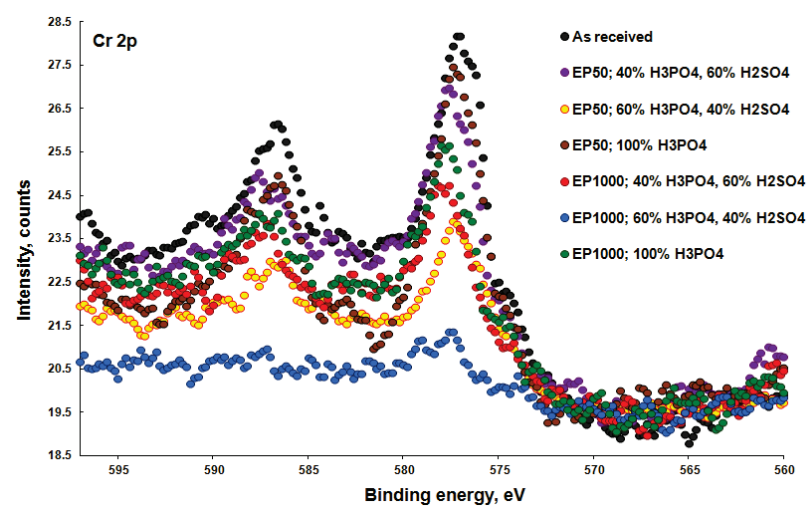

Figure 2 XPS results of chromium (Cr 2p) of AISI 316L SS after HDEP

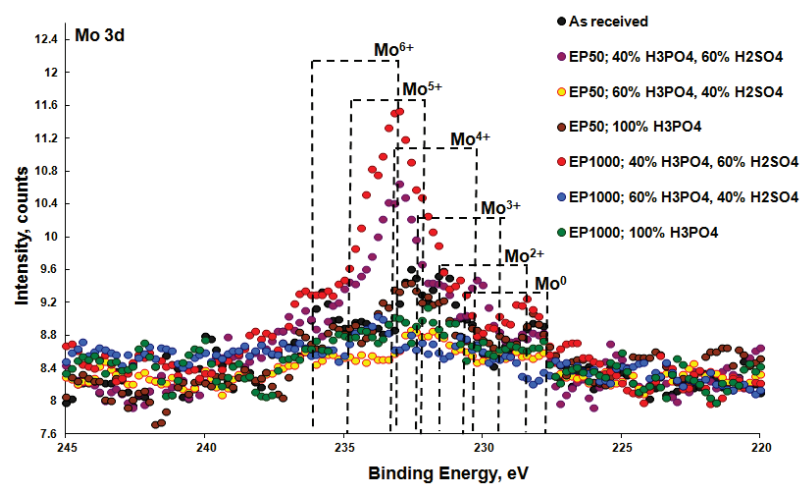

Figure 3 XPS results of molybdenum (Mo 3d) of AISI 316L SS after HDEP

Manganese spectra shown in Fig. 4 demonstrate that most of $\mathrm{Mn}$ was detected in samples without electrochemical treatment (as received) and the lowest one after electropolishing in 60 vol. $\% \mathrm{H}_{3} \mathrm{PO}_{4} \& 40$ vol.\% $\mathrm{H}_{2} \mathrm{SO}_{4}$ solution $\left(i=1000 \mathrm{~A} / \mathrm{dm}^{2}\right)$. There were detected all states of manganese oxidation, i.e. $\mathrm{Mn}^{2+}, \mathrm{Mn}^{3+}, \mathrm{Mn}^{4+}$. On the basis of available literature $[36,37]$ the most probable composition of all surface layers formed after electrochemical polishing were the following manganese compounds: $\mathrm{MnS}, \mathrm{MnO}, \mathrm{MnFe}_{2} \mathrm{O}_{4}, \mathrm{MnCr}_{2} \mathrm{O}_{4}, \mathrm{Mn}_{3} \mathrm{O}_{4}$, $\mathrm{Mn}_{2} \mathrm{O}_{3}, \mathrm{MnO}_{2}, \mathrm{MnOOH}, \mathrm{MnSO}_{4}$. The authors speculate that manganese phosphates could be located in the surface layers formed in the solutions containing phosphoric acid. These manganese phosphates have not been plotted there in Fig. 4 because of no available literature data. There are no standards for those compounds.

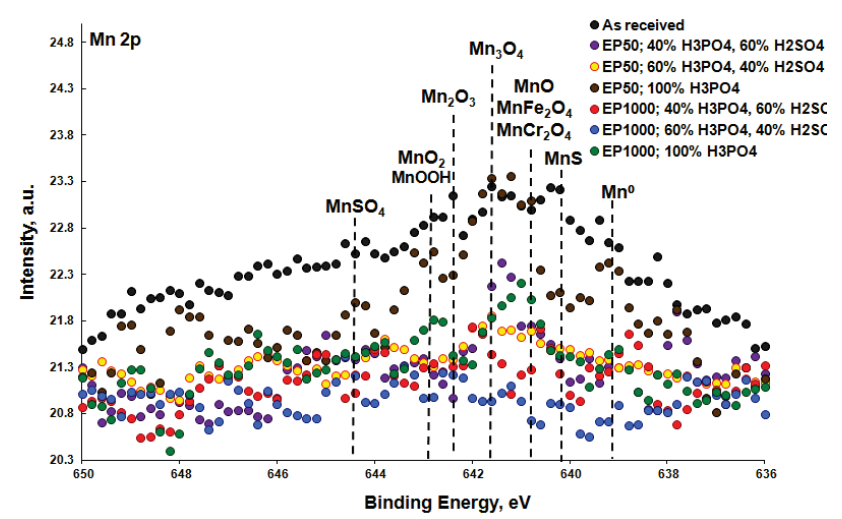

Figure 4 XPS results of manganese (Mn 2p) of AISI 316L SS after HDEP

In Fig. 5 there are spectra of nickel (Ni2p) presented. Most of the nickel content $(\mathrm{NiO})$ [36] was detected in the surface layer of the sample without electrochemical treatment (as received) as well as after electrochemical polishing in pure $\mathrm{H}_{3} \mathrm{PO}_{4}\left(i=50 \mathrm{~A} / \mathrm{dm}^{2}\right)$. The low amount of nickel was observed after electropolishing in $60 \mathrm{vol} \%$ $\mathrm{H}_{3} \mathrm{PO}_{4} \& 40$ vol\% $\mathrm{H}_{2} \mathrm{SO}_{4}$ solution when applying the current density of $50 \mathrm{~A} / \mathrm{dm}^{2}$. In case of electrochemical treatment in the 60 vol\% $\mathrm{H}_{3} \mathrm{PO}_{4} \& 40 \mathrm{vol} \% \mathrm{H}_{2} \mathrm{SO}_{4}$ solution and current density $1000 \mathrm{~A} / \mathrm{dm}^{2}$ there was no nickel detected. It is very important and useful information because of nickel commonly recognized as a carcinogenic element for human body and it is undesirable in the case of biomaterials.

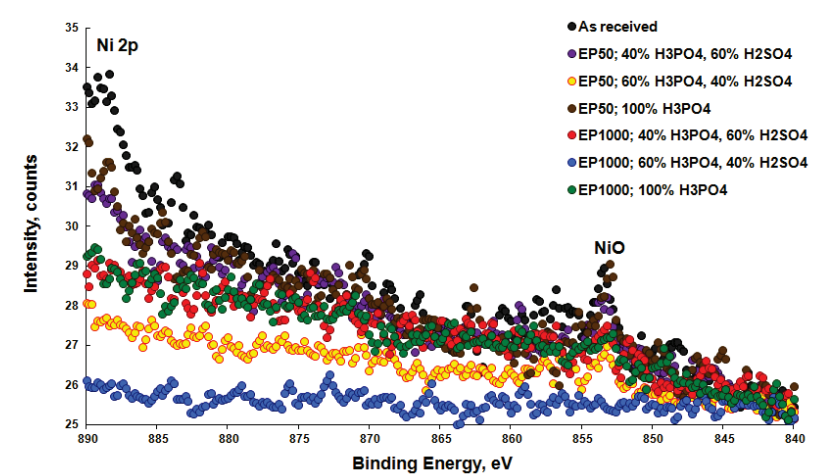

Figure 5 XPS results of nickel (Ni 2p) of AISI 316L SS after HDEP

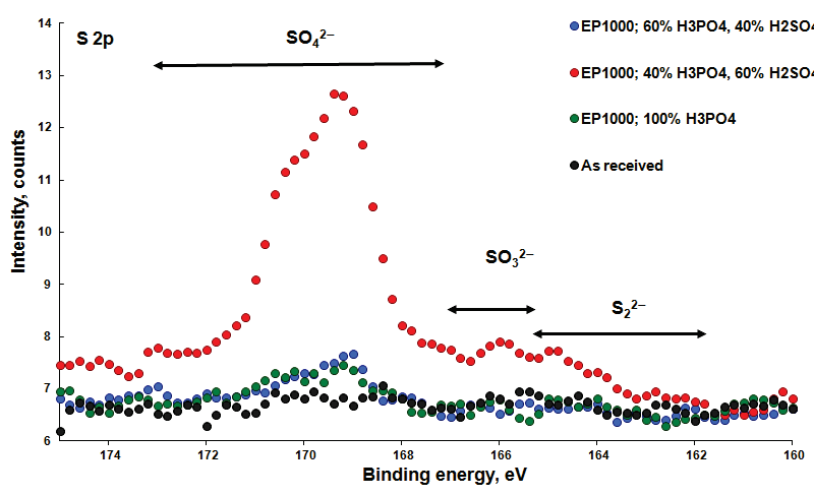

Figure 6 XPS results of sulfur (S 2p) of AISI 316L SS after HDEP

In Figs. $6 \div 9$ there are sulfur (S 2p), phosphorus ( $\mathrm{P}$ $2 \mathrm{p})$, oxygen $(\mathrm{O} 1 \mathrm{~s})$, and carbon $(\mathrm{C} 1 \mathrm{~s})$ spectra reported, respectively. The sulfur in the surface layer is presented mostly by sulfates and considerably less in the form of sulfite or sulfides. Phosphorus occurs in the form of 
phosphates. On the basis of O 1s spectra analysis (Fig. 8) it is possible to confirm the previous finding arising from sulfur and phosphorus spectra. Carbon spectra shown in Fig. 9 provide the information about the amount of carbon-oxygen compounds, which should be considered as contaminants $[36,38]$.

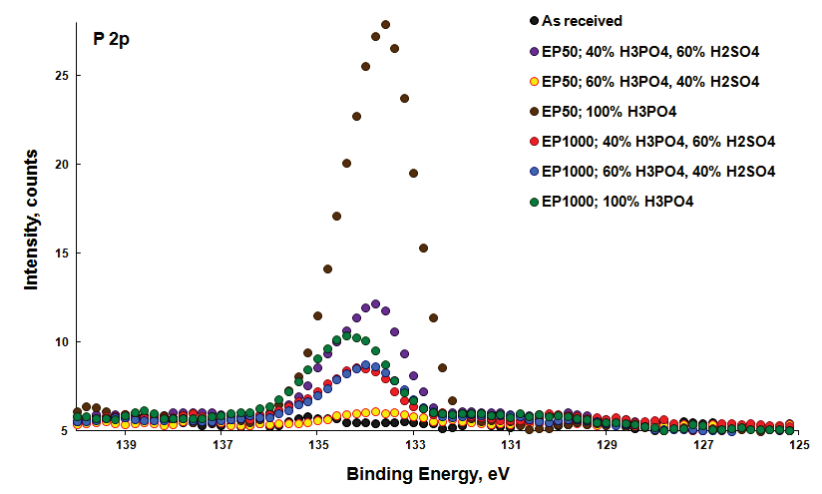

Figure 7 XPS results of phosphorus (P 2p) of AISI 316L SS after HDEP

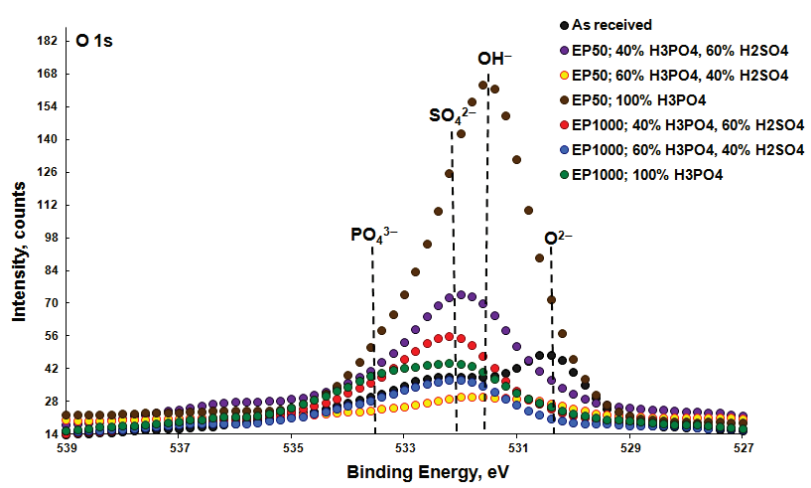

Figure 8 XPS results of oxygen (O 1s) of AISI 316L SS after HDEP



Figure 9 XPS results of carbon (C 1s) of AISI 316L SS after HDEP in different solutions

In Tab. 3 there are complex data of surface layers formed after electropolishing treatment in different solutions and with other current densities. The selected data for chromium, iron and molybdenum are presented in Fig. 10. The experiment plan assumes three levels of the phosphoric acid to sulfuric acid volume ratios, i.e. (a) 40 vol $\%$ : $60 \mathrm{vol} \%$; (b) $60 \mathrm{vol} \%: 40 \mathrm{vol} \%$; and (c) $100 \mathrm{vol} \%$ : $0 \mathrm{vol} \%$, respectively, with additional data of non-treated (as received) surface layer sample. The highest amount of iron and nickel was noted for non-electropolished sample, while the greatest enrichment in chromium was observed after electrochemical polishing in $60 \mathrm{vol} \% \mathrm{H}_{3} \mathrm{PO}_{4} \& 40$ vol $\% \mathrm{H}_{2} \mathrm{SO}_{4}$ solution when applying the current density of $50 \mathrm{~A} / \mathrm{dm}^{2}$. The other chemical element of the steel composition - molybdenum, which appears to be important for impeding the pitting corrosion, presented its highest amount after electrochemical treatment in 40 vol $\% \mathrm{H}_{3} \mathrm{PO}_{4}$ and $60 \mathrm{vol} \% \mathrm{H}_{2} \mathrm{SO}_{4}$ solution with using the current density equal to $50 \mathrm{~A} / \mathrm{dm}^{2}$.

\begin{tabular}{|c|c|c|c|c|c|c|c|}
\hline & AR & EP50 & EP1000 & EP50 & EP1000 & EP50 & EP1000 \\
\hline $\mathrm{H}_{3} \mathrm{PO}_{4}:$ & - & $40 \%$ & $40 \%$ & $60 \%$ & $60 \%$ & $100 \%$ & $100 \%$ \\
\hline $\mathrm{H}_{2} \mathrm{SO}_{4}:$ & - & $60 \%$ & $60 \%$ & $40 \%$ & $40 \%$ & $0 \%$ & $0 \%$ \\
\hline $\mathrm{Fe}$ & 5,6 & 1,9 & 1,5 & 3,2 & 0,5 & 3,0 & 0,8 \\
\hline $\mathrm{Cr}$ & 2,5 & 1,6 & 1,7 & 3,5 & 0,5 & 2,5 & 1,3 \\
\hline Mo & 0,8 & 0,8 & 1,1 & 0,9 & 0,1 & 0,6 & 0,4 \\
\hline $\mathrm{Ni}$ & 0,5 & 0,1 & 0,1 & 0,4 & 0 & 0,4 & 0,1 \\
\hline $\mathrm{Mn}$ & 1,3 & 0,5 & 0,3 & 1,8 & 0 & 1,1 & 0,4 \\
\hline $\mathrm{O}$ & 44,8 & 51,2 & 35,0 & 42,6 & 26,7 & 76,6 & 36,8 \\
\hline $\mathrm{P}$ & 0 & 6,1 & 3,0 & 3,3 & 3,1 & 15,8 & 5,4 \\
\hline $\mathrm{S}$ & 0 & 3,0 & 5,0 & 1,2 & 0,5 & 0 & 0,9 \\
\hline $\mathrm{C}$ & 44,5 & 34,8 & 52,3 & 43,1 & 68,6 & - & 53,9 \\
\hline
\end{tabular}

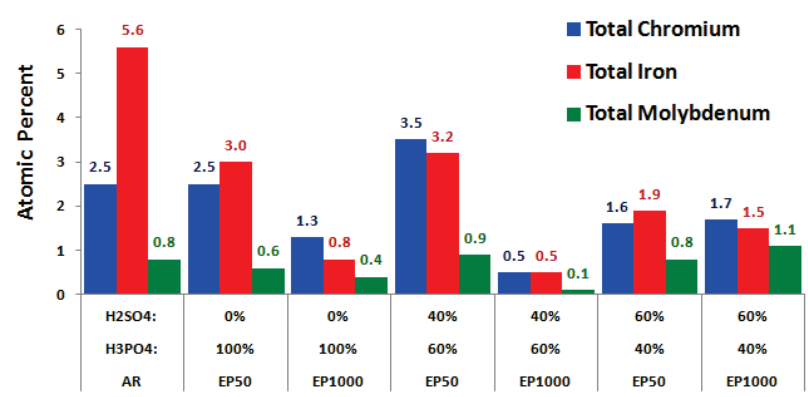

Figure 10 Atomic percent of total amount (metal plus compounds) of chromium, iron and molybdenum of AISI 316L SS surface layer formed by HDEP (on the basis of Tab. 3 data)

Taking advantage of Tab. 3, proposed by the Authors, pitting coefficient $(\mathrm{Cr} / \mathrm{Fe}+3,3 \cdot \mathrm{Mo} / \mathrm{Fe})$ was calculated together with the data presented in Tab. 4 and Fig. 11. On the basis of the obtained data one may easily notice that the best pitting corrosion resistance should be expected on the AISI 316L sample with the surface layer formed after electrochemical polishing in $40 \mathrm{vol} \% \mathrm{H}_{3} \mathrm{PO}_{4} \& 60 \mathrm{vol} \%$ $\mathrm{H}_{2} \mathrm{SO}_{4}$ at current density equal to $1000 \mathrm{~A} / \mathrm{dm}^{2}$ as well as after electro-treatment in pure phosphoric acid and also for the same current density $1000 \mathrm{~A} / \mathrm{dm}^{2}$.

Table 4 Pitting coefficient calculated on the basis of data contained in

\begin{tabular}{|c|c|c|c|c|c|c|}
\hline & $\mathrm{H}_{3} \mathrm{PO}_{4}$ & $\mathrm{H}_{2} \mathrm{SO}_{4}$ & $\mathrm{Fe}$ & $\mathrm{Cr}$ & $\mathrm{Mo}$ & $(\mathrm{Cr}+3,3 \cdot \mathrm{Mo}) / \mathrm{Fe}$ \\
\hline AR & - & - & 5,6 & 2,5 & 0,8 & 0,9 \\
\hline EP50 & $100 \%$ & $0 \%$ & 3 & 2,5 & 0,6 & 1,5 \\
\hline EP1000 & $100 \%$ & $0 \%$ & 0,8 & 1,3 & 0,4 & 3,3 \\
\hline EP50 & $60 \%$ & $40 \%$ & 3,2 & 3,5 & 0,9 & 2 \\
\hline EP1000 & $60 \%$ & $40 \%$ & 0,5 & 0,5 & 0,1 & 1,7 \\
\hline EP50 & $40 \%$ & $60 \%$ & 1,9 & 1,6 & 0,8 & 2,2 \\
\hline EP1000 & $40 \%$ & $60 \%$ & 1,5 & 1,7 & 1,1 & 3,6 \\
\hline
\end{tabular}

In Tabs. $5 \div 10$, there are detailed analyses of chromium $\mathrm{Cr} 2 \mathrm{p}$ and iron Fe $2 \mathrm{p}$ spectra of the steel surface layers formed after consecutive electrochemical treatments. For iron $\mathrm{Fe} 2 \mathrm{p}$ spectra analysis the single reference peaks [36] were used. Chromium $\mathrm{Cr} 2 \mathrm{p}$ spectra by single peaks $\left(\mathrm{Cr}^{0}, \mathrm{CrOOH} / \mathrm{Cr}(\mathrm{OH})_{3}, \mathrm{Cr}_{2}\left(\mathrm{SO}_{4}\right)_{3}, \mathrm{CrPO}_{4}\right.$, $\mathrm{CrO}_{4}{ }^{2-},\left(\mathrm{Cr}^{6+}\right)$ as well as by multiple splitting peaks [39] $\left(\mathrm{Cr}_{2} \mathrm{O}_{3}\right)$ were fitted. 


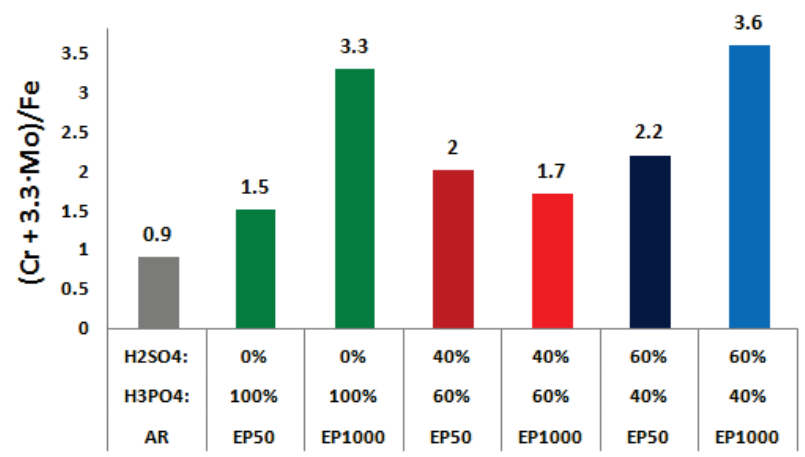

Figure $11(\mathrm{Cr}+3.3 \cdot \mathrm{Mo}) / \mathrm{Fe}$ ratio of AISI 316L SS after HDEP

In Fig. 12 and Tabs. 5 and 6 (Fe 2p spectra analysis) as well as in Fig. 13 and Tabs. 7 and 8 (Cr 2p spectra analysis), there are shown surface layer compositions after electrochemical polishing in $40 \mathrm{vol} \% \mathrm{H}_{3} \mathrm{PO}_{4}$ and 60 vol $\% \mathrm{H}_{2} \mathrm{SO}_{4}$ solution at two current densities, i.e. 50 $\mathrm{A} / \mathrm{dm}^{2}$ (EP50) and $1000 \mathrm{~A} / \mathrm{dm}^{2}$ (EP1000). In the two analyzed surface layers there were detected the same iron compounds, but with a different quantity/content. More metallic iron was detected after the treatment at $50 \mathrm{~A} / \mathrm{dm}^{2}$ than after the one at $1000 \mathrm{~A} / \mathrm{dm}^{2}$. The peak neighbouring the metallic one can be interpreted as iron sulfide. After EP50 treatment there were detected about three times more of those compounds than in the surface layer after EP1000. The amounts of iron oxides $\left(\mathrm{FeO}, \mathrm{Fe}_{2} \mathrm{O}_{3}, \mathrm{Fe}_{3} \mathrm{O}_{4}\right)$ for the two treatments were very similar, i.e. about 2 at $\%$.
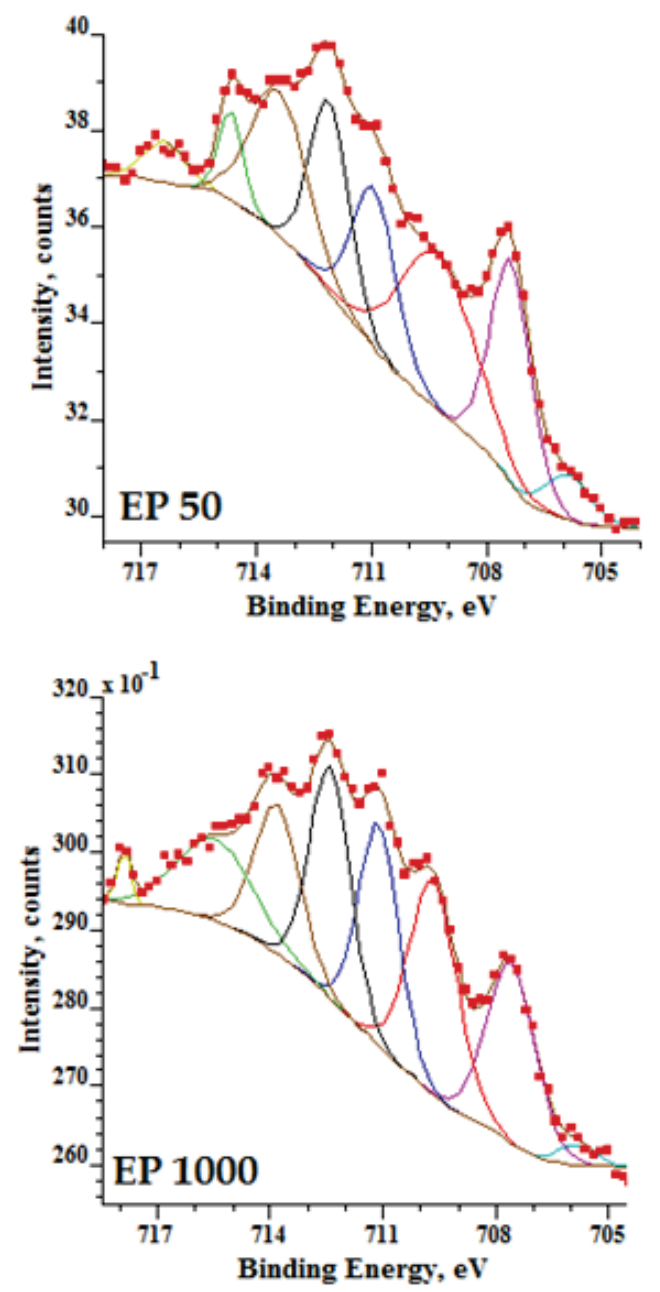

Figure 12 Fitting Fe 2p3/2 for EP50 \& EP1000 data (electrolyte: 40 vol $\% \mathrm{H}_{3} \mathrm{PO}_{4} \& 60$ vol $\% \mathrm{H}_{2} \mathrm{SO}_{4}$ )
Table 5 Results of fitting Fe 2p3/2 for EP 50 data (electrolyte: 40 vol\%

\begin{tabular}{|c|c|c|c|c|}
\hline \multicolumn{5}{|c|}{$\mathrm{H}_{3} \mathrm{PO}^{4} \& 60$ vol $\left.\% \mathrm{H}_{2} \mathrm{SO}_{4}\right)$} \\
\hline $\mathrm{BE} / \mathrm{eV}$ & FWHM & $\begin{array}{c}\text { Fe } 2 \mathrm{p} / \\
\text { at } \%\end{array}$ & Iron compounds & Ref. \\
\hline 705,9 & 1,4 & 4,1 & Fe-S & \multirow{4}{*}[36,41,42]{} \\
\hline 707,4 & 1,2 & 18,2 & $\mathrm{Fe}^{0}$ & \\
\hline 707,4 & 2,1 & 23,8 & $\mathrm{FeO}, \mathrm{Fe}_{3} \mathrm{O}_{4}, \mathrm{Fe}^{2+}$ & \\
\hline 710,9 & 1,3 & 14,3 & $\mathrm{Fe}_{2} \mathrm{O}_{3}, \mathrm{Fe}_{3} \mathrm{O}_{4}, \mathrm{Fe}^{3+}$ & \\
\hline 712,1 & 1,2 & 15,2 & $\mathrm{FeSO}_{4}$ & {$[41 \div 43]$} \\
\hline 713,4 & 1,7 & 16,6 & $\mathrm{Fe}_{2}\left(\mathrm{SO}_{4}\right)_{3}$ & {$[42,43]$} \\
\hline 714,6 & 0,7 & 4,4 & \multirow{2}{*}{$\begin{array}{c}\mathrm{Fe}_{3}\left(\mathrm{PO}_{4}\right)_{2}, \mathrm{FePO}_{4} \\
\text { sat }\left(\mathrm{Fe}^{2+}\right)\end{array}$} & \multirow{2}{*}[44,45]{} \\
\hline 716,4 & 1,3 & 3,4 & & \\
\hline
\end{tabular}

Table 6 Results of fitting Fe 2p3/2 for EP1000 data (electrolyte: 40

\begin{tabular}{|c|c|c|c|c|}
\hline $\mathrm{BE} / \mathrm{eV}$ & FWHM & $\begin{array}{c}\mathrm{Fe} 2 \mathrm{p} / \\
\text { at } \%\end{array}$ & Iron compounds & Ref. \\
\hline 705,9 & 1,2 & 1,4 & $\mathrm{Fe}-\mathrm{S}$ & \multirow{4}{*}[36,41,42]{} \\
\hline 707,6 & 1,5 & 16,8 & $\mathrm{Fe}^{0}$ & \\
\hline 709,7 & 1,5 & 20,0 & $\mathrm{FeO}, \mathrm{Fe}_{3} \mathrm{O}_{4}, \mathrm{Fe}^{2+}$ & \\
\hline $\begin{array}{lll}711,1 \\
\end{array}$ & 1,3 & 17,3 & $\mathrm{Fe}_{2} \mathrm{O}_{3}, \mathrm{Fe}_{3} \mathrm{O}_{4}, \mathrm{Fe}^{3+}$ & \\
\hline 712,4 & 1,3 & 18,3 & $\mathrm{FeSO}_{4}$ & {$[41 \div 43]$} \\
\hline 713,8 & 1,4 & 13,0 & $\mathrm{Fe}_{2}\left(\mathrm{SO}_{4}\right)_{3}$ & {$[42,43]$} \\
\hline 715,5 & 2,3 & 11,8 & \multirow{2}{*}{$\begin{array}{c}\mathrm{Fe}_{3}\left(\mathrm{PO}_{4}\right)_{2}, \mathrm{FePO}_{4} \\
\operatorname{sat}\left(\mathrm{Fe}^{2+}\right)\end{array}$} & \multirow{2}{*}[44,45]{} \\
\hline 717,9 & 0,4 & 1,4 & & \\
\hline
\end{tabular}
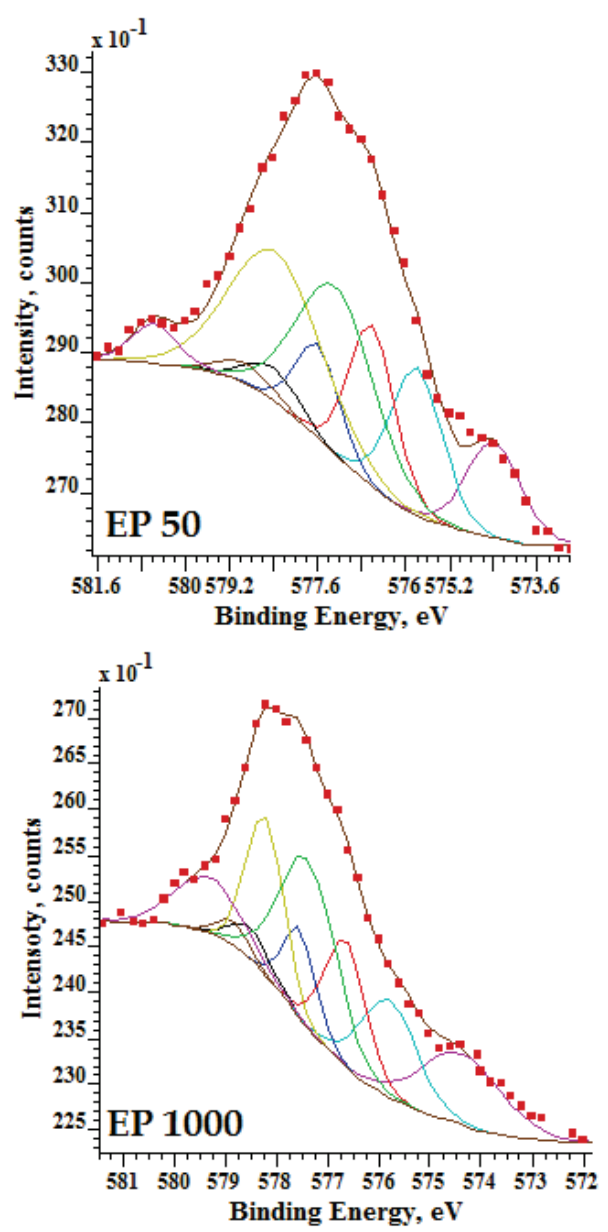

Figure 13 Fitting Fe 2p3/2 for EP50 \& EP1000 data (electrolyte: 40 vol $\% \mathrm{H}_{3} \mathrm{PO}_{4} \& 60$ vol $\% \mathrm{H}_{2} \mathrm{SO}_{4}$ )

The difference (about 5 at \%) in case of sulfates and phosphates of iron has been observed. It should be noted that most of these salts are sulfates of iron, which are well soluble in water. That way the iron sulfates after immersion in e.g. a distiller water or in Ringer's solution, most probably will undergo dissolution, what in consequence will increase the chromium-compounds to iron-compounds ratio. The passive layer should remain in 
the form of oxides, hydroxides and phosphates of iron as well as iron sulfides. Regarding the content of chromium metal it should be noted that the difference between EP50 and EP1000 is about 5 at\%. In case of chromium III oxide there is the same amount in both layers, but there is a big difference in case of chromium hydroxide, which is about 10 at $\%$.

Table 7 Results of fitting Cr 2p3/2 for EP50 data (electrolyte: 40 vol\%

\begin{tabular}{|c|c|c|c|c|}
\hline \multicolumn{5}{|c|}{$\left.\mathrm{H}_{3} \mathrm{PO}_{4} \& 60 \mathrm{vol} \% \mathrm{H}_{2} \mathrm{SO}_{4}\right)$} \\
\hline $\mathrm{BE} / \mathrm{eV}$ & FWHM & $\begin{array}{c}\mathrm{Cr} 2 \mathrm{p} / \\
\text { at } \%\end{array}$ & Chromium compounds & Ref. \\
\hline 574,4 & 1,1 & 9,3 & $\mathrm{Cr}^{0}$ & [36] \\
\hline 575,7 & 1,1 & 13,6 & \multirow{5}{*}{$\begin{array}{l}\mathrm{Cr}_{2} \mathrm{O}_{3} \\
\left(\mathrm{Cr}^{3+}\right)\end{array}$} & \multirow{8}{*}{$\stackrel{\infty}{+\infty}$} \\
\hline 576,7 & 1,0 & 13,2 & & \\
\hline 577,5 & 0,9 & 7,2 & & \\
\hline 578,4 & 1,1 & 3,0 & & \\
\hline 578,9 & 1,1 & 2,0 & & \\
\hline 577,3 & 1,7 & 23,3 & $\begin{array}{c}\mathrm{CrOOH}, \mathrm{Cr}(\mathrm{OH})_{3} \\
\left(\mathrm{Cr}^{3+}\right)\end{array}$ & \\
\hline 578,4 & 2,0 & 25,1 & $\mathrm{Cr}_{2}\left(\mathrm{SO}_{4}\right)_{3}, \mathrm{CrPO}_{4},\left(\mathrm{Cr}^{3+}\right)$ & \\
\hline 580,6 & 1,0 & 3,3 & $\left(\mathrm{CrO}_{4}\right)^{2}, \mathrm{Cr}^{6+}$ & \\
\hline
\end{tabular}

Table 8 Results of fitting Cr 2p3/2 for EP1000 data (electrolyte: 40 vol $\% \mathrm{H}_{3} \mathrm{PO}_{4} \& 60$ vol $\% \mathrm{H}_{2} \mathrm{SO}_{4}$ )

\begin{tabular}{|c|c|c|c|c|}
\hline $\mathrm{BE} / \mathrm{eV}$ & FWHM & $\begin{array}{c}\mathrm{Cr} 2 \mathrm{p} / \\
\mathrm{at} \%\end{array}$ & Chromium compounds & Ref. \\
\hline 574,4 & 1,8 & 14,1 & $\mathrm{Cr}^{0}$ & {$[36]$} \\
\hline 575,7 & 1,3 & 13,4 & \multirow{5}{*}{$\begin{array}{l}\mathrm{Cr}_{2} \mathrm{O}_{3} \\
\left(\mathrm{Cr}^{3+}\right)\end{array}$} & \multirow{8}{*}{ 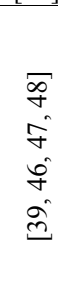 } \\
\hline 576,7 & 1,0 & 13,0 & & \\
\hline 577,5 & 0,7 & 7,1 & & \\
\hline 578,5 & 0,9 & 3,0 & & \\
\hline 578,9 & 0,7 & 1,9 & & \\
\hline 577,3 & 1,3 & 23,8 & $\begin{array}{c}\mathrm{CrOOH}, \mathrm{Cr}(\mathrm{OH})_{3} \\
\left(\mathrm{Cr}^{3+}\right)\end{array}$ & \\
\hline 578,1 & 0,9 & 14,7 & $\mathrm{Cr}_{2}\left(\mathrm{SO}_{4}\right)_{3}, \mathrm{CrPO}_{4},\left(\mathrm{Cr}^{3+}\right)$ & \\
\hline 579,3 & 1,5 & 9,0 & $\left(\mathrm{CrO}_{4}\right)^{2}, \mathrm{Cr}^{6+}$ & \\
\hline
\end{tabular}

There is a noticeably higher amount of chromium on the sixth oxidation stage (about three times more in surface layer after EP1000 than that after EP50) which may sensitize the human body, and/or in a higher dosage can be carcinogenic [40]. In Figs. 14 and 15 and Tabs. $9 \div$ 12 , there are reported results after electrochemical polishing in 60 vol $\% \mathrm{H}_{3} \mathrm{PO}_{4}$ and $40 \mathrm{vol} \% \mathrm{H}_{2} \mathrm{SO}_{4}$ solution when applying the current densities of 50 and 1000 $\mathrm{A} / \mathrm{dm}^{2}$, respectively.

Table 9 Results of fitting Fe 2p3/2 for EP 50 data ( $60 \mathrm{vol} \% \mathrm{H}_{3} \mathrm{PO}_{4} \& 40$ vol $\% \mathrm{H}_{2} \mathrm{SO}_{4}$ )

\begin{tabular}{|c|c|c|c|c|}
\hline \multicolumn{5}{|c|}{ 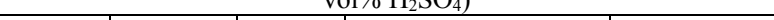 } \\
\hline $\mathrm{BE} / \mathrm{eV}$ & FWHM & $\begin{array}{c}\text { Fe } 2 \mathrm{p} / \\
\text { at } \%\end{array}$ & Iron compounds & Ref. \\
\hline 705,8 & 0,8 & 4,6 & $\mathrm{Fe}-\mathrm{S}$ & \multirow{5}{*}[36,41,42]{} \\
\hline 707,2 & 1,3 & 29,4 & $\mathrm{Fe}^{0}$ & \\
\hline 708,2 & 1,3 & 17,1 & $\mathrm{FeO}, \mathrm{Fe}_{3} \mathrm{O}_{4}, \mathrm{Fe}^{2+}$ & \\
\hline 710,1 & 1,8 & 21,4 & $\mathrm{Fe}_{2} \mathrm{O}_{3}, \mathrm{Fe}_{3} \mathrm{O}_{4}, \mathrm{Fe}^{3+}$ & \\
\hline 711,8 & 1,5 & 19,7 & $\mathrm{FeOOH}, \mathrm{Fe}^{3+}$ & \\
\hline 713,40 & 1,0 & 5,9 & \multirow{2}{*}{$\begin{array}{c}\mathrm{Fe}_{2}\left(\mathrm{SO}_{4}\right)_{3}, \mathrm{Fe}_{3}\left(\mathrm{PO}_{4}\right)_{2}, \\
\mathrm{FePO}_{4}, \operatorname{sat}\left(\mathrm{Fe}^{2+}\right) \\
\mathrm{Fe}^{2+} \& \mathrm{Fe}^{3+}\end{array}$} & \multirow[b]{2}{*}[42\div45]{} \\
\hline 717,1 & 0,8 & 1,9 & & \\
\hline
\end{tabular}

Table 10 Results of fitting Fe 2p3/2 for EP 1000 data (60 vol $\% \mathrm{H}_{3} \mathrm{PO}_{4}$

\begin{tabular}{|c|c|c|c|c|}
\hline $\mathrm{BE} / \mathrm{eV}$ & FWHM & $\begin{array}{c}\mathrm{Fe} 2 \mathrm{p} / \\
\mathrm{at} \%\end{array}$ & Iron compounds & Ref. \\
\hline 707,1 & 0,7 & 2,5 & $\mathrm{Fe}^{0}$ & \multirow{4}{*}[36,41,42]{} \\
\hline 708,9 & 1,0 & 13,0 & $\mathrm{FeO}, \mathrm{Fe}_{3} \mathrm{O}_{4}, \mathrm{Fe}^{2+}$ & \\
\hline 710,2 & 1,2 & 11,0 & $\mathrm{Fe}_{2} \mathrm{O}_{3}, \mathrm{Fe}_{3} \mathrm{O}_{4}, \mathrm{Fe}^{3+}$ & \\
\hline 711,5 & 1,2 & 24,7 & $\mathrm{FeOOH}, \mathrm{Fe}^{3+}$ & \\
\hline 712,9 & 1,4 & 30,0 & \multirow{3}{*}{$\begin{array}{c}\mathrm{Fe}_{2}\left(\mathrm{SO}_{4}\right)_{3}, \mathrm{Fe}_{3}\left(\mathrm{PO}_{4}\right)_{2}, \\
\mathrm{FePO}_{4}, \operatorname{sat}\left(\mathrm{Fe}^{2+}\right) \\
\mathrm{Fe}^{2+} \& \mathrm{Fe}^{3+}\end{array}$} & \multirow{3}{*}[42\div45]{} \\
\hline 714,2 & 1,5 & 12,4 & & \\
\hline 715,4 & 0,7 & 5,2 & & \\
\hline
\end{tabular}
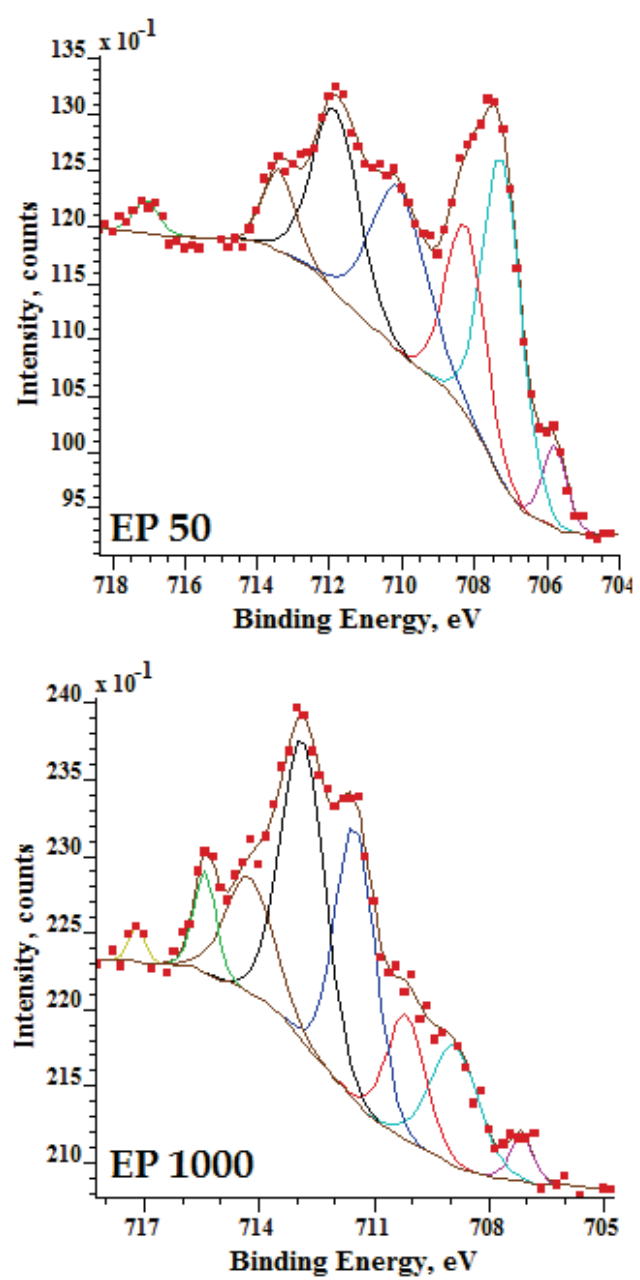

Figure 14 Fitting Fe 2p3/2 for EP 50 \& EP 1000 data $\left(60\right.$ vol $\% \mathrm{H}_{3} \mathrm{PO}_{4}$ \& $40 \mathrm{vol} \% \mathrm{H}_{2} \mathrm{SO}_{4}$ )

In that electrolyte $\left(\begin{array}{lllllll}60 & \text { vol } \% & \mathrm{H}_{3} \mathrm{PO}_{4} & \& & 40 & \mathrm{vol} \%\end{array}\right.$ $\mathrm{H}_{2} \mathrm{SO}_{4}$ ) after electrochemical treatment at $50 \mathrm{~A} / \mathrm{dm}^{2}$, the steel surface layer reveals about two times more iron sulfides than after electropolishing at $1000 \mathrm{~A} / \mathrm{dm}^{2}$. More oxides and hydroxides of iron are observed in the passive layer after EP1000 than after EP50 by about 7,5 at\%. Over two times more sulfates and phosphates of iron were detected in the passive layer after EP1000.

Table 11 Results of fitting Cr 2p3/2 for EP 50 data (electrolyte: $60 \mathrm{vol} \%$ $\mathrm{H}_{3} \mathrm{PO}_{4} \& 40$ vol $\left.\% \mathrm{H}_{2} \mathrm{SO}_{4}\right)$

\begin{tabular}{|c|c|c|c|c|}
\hline $\mathrm{BE} / \mathrm{eV}$ & FWHM & $\begin{array}{c}\mathrm{Cr} 2 \mathrm{p} / \\
\text { at } \%\end{array}$ & Chromium compounds & Ref. \\
\hline 574,4 & 1,5 & 16,3 & $\mathrm{Cr}^{0}$ & {$[36]$} \\
\hline 575,7 & 1,1 & 17,9 & \multirow{5}{*}{$\begin{array}{l}\mathrm{Cr}_{2} \mathrm{O}_{3} \\
\left(\mathrm{Cr}^{3+}\right)\end{array}$} & \multirow{8}{*}{$\begin{array}{l}\infty \\
\dot{+} \\
\tilde{\sigma} \\
\dot{+} \\
\dot{+} \\
\hat{0}\end{array}$} \\
\hline 576,5 & 1,1 & 17,4 & & \\
\hline 577,4 & 0,9 & 9,5 & & \\
\hline 578,4 & 1,1 & 3,9 & & \\
\hline 578,9 & 0,9 & 2,5 & & \\
\hline 577,3 & 1,5 & 23,5 & $\begin{array}{c}\mathrm{CrOOH}, \mathrm{Cr}(\mathrm{OH})_{3} \\
\left(\mathrm{Cr}^{3+}\right)\end{array}$ & \\
\hline 578,2 & 1,1 & 7,4 & $\mathrm{Cr}_{2}\left(\mathrm{SO}_{4}\right)_{3}, \mathrm{CrPO}_{4},\left(\mathrm{Cr}^{3+}\right)$ & \\
\hline 579,4 & 0,8 & 1,6 & $\left(\mathrm{CrO}_{4}\right)^{2}, \mathrm{Cr}^{6+}$ & \\
\hline
\end{tabular}

In case of chromium compounds analysis, there are observed over two times more chromium III oxide as well as more chromium III hydroxides with about 3 at $\%$ after EP50 than after EP1000. It is more important, however, that after a standard electrochemical treatment EP50 there is over 14 times less chromium content on the sixth oxidation stage than that after EP1000. 

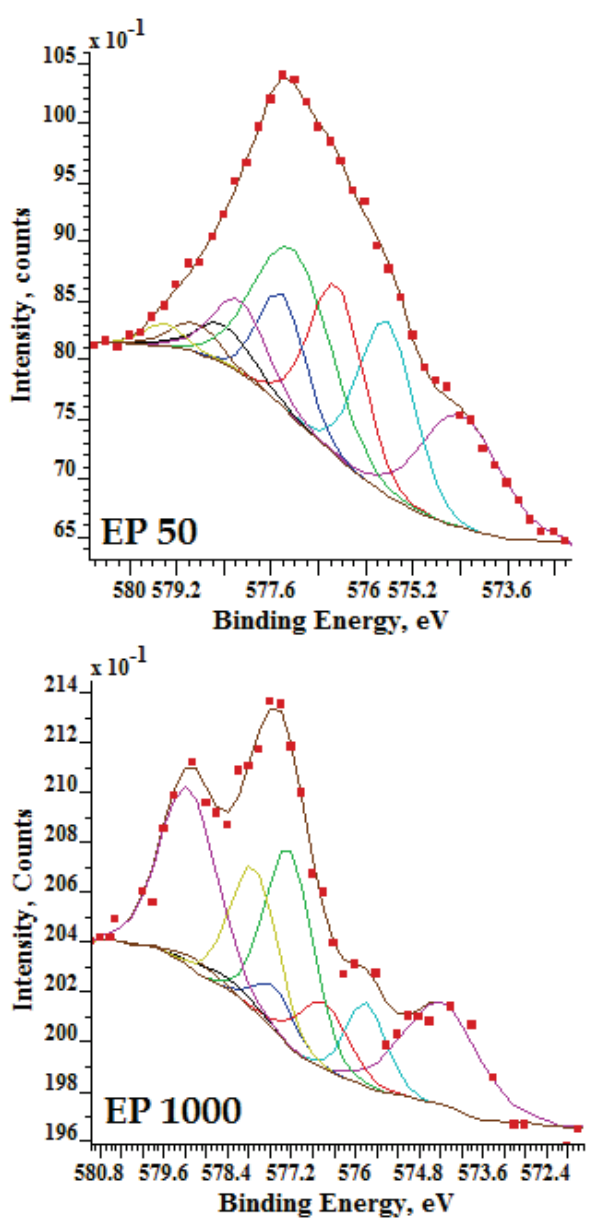

Figure 15 Fitting Cr 2p3/2 for EP 50 \& EP1000 data $\left(60\right.$ vol $\% \mathrm{H}_{3} \mathrm{PO}_{4}$ \& $40 \mathrm{vol} \% \mathrm{H}_{2} \mathrm{SO}_{4}$ )

Table 12 Results of fitting Cr 2p3/2 for EP 1000 data (electrolyte: 60 vol $\% \mathrm{H}_{3} \mathrm{PO}_{4} \& 40$ vol $\% \mathrm{H}_{2} \mathrm{SO}_{4}$ )

\begin{tabular}{|c|c|c|c|c|}
\hline $\mathrm{BE} / \mathrm{eV}$ & FWHM & $\begin{array}{c}\mathrm{Cr} 2 \mathrm{p} / \\
\mathrm{at} \%\end{array}$ & Chromium compounds & Ref. \\
\hline 574,4 & 1,7 & 17,9 & $\mathrm{Cr}^{0}$ & {$[36]$} \\
\hline 575,7 & 0,9 & 7,6 & \multirow{5}{*}{$\begin{array}{l}\mathrm{Cr}_{2} \mathrm{O}_{3} \\
\left(\mathrm{Cr}^{3+}\right)\end{array}$} & \multirow{8}{*}{  } \\
\hline 576,5 & 1,1 & 7,4 & & \\
\hline 577,5 & 0,9 & 4,1 & & \\
\hline 578,5 & 1,2 & 1,7 & & \\
\hline 578,9 & 0,9 & 1,1 & & \\
\hline 577,3 & 1,1 & 21,4 & $\begin{array}{c}\mathrm{CrOOH}, \mathrm{Cr}(\mathrm{OH})_{3} \\
\left(\mathrm{Cr}^{3+}\right)\end{array}$ & \\
\hline 577,9 & 1,1 & 15,6 & $\mathrm{Cr}_{2}\left(\mathrm{SO}_{4}\right)_{3}, \mathrm{CrPO}_{4},\left(\mathrm{Cr}^{3+}\right)$ & \\
\hline 579,1 & 1,3 & 23,2 & $\left(\mathrm{CrO}_{4}\right)^{2}, \mathrm{Cr}^{6+}$ & \\
\hline
\end{tabular}

In Fig. 16 and Tabs. $13 \div 16$, there are shown results of fitting after electrochemical polishing in pure $\mathrm{H}_{3} \mathrm{PO}_{4}$ when applying the current densities of 50 and 1000 $\mathrm{A} / \mathrm{dm}^{2}$.

Table 13 Results of fitting Fe 2p3/2 for EP50 data (electrolyte: pure

\begin{tabular}{|c|c|c|c|c|}
\hline \multicolumn{5}{|c|}{$\left.\mathrm{H}_{3} \mathrm{PO}_{4}\right)$} \\
\hline $\mathrm{BE} / \mathrm{eV}$ & FWHM & $\begin{array}{c}\mathrm{Fe} 2 \mathrm{p} / \\
\text { at } \%\end{array}$ & Iron compounds & Ref. \\
\hline 707,2 & 1,3 & 14,5 & $\mathrm{Fe}^{0}$ & \multirow{4}{*}[36,41,42]{} \\
\hline 708,8 & 1,2 & 7,2 & $\mathrm{FeO}, \mathrm{Fe}_{3} \mathrm{O}_{4}, \mathrm{Fe}^{2+}$ & \\
\hline 709,8 & 1,4 & 13,6 & $\mathrm{Fe}_{2} \mathrm{O}_{3}, \mathrm{Fe}_{3} \mathrm{O}_{4}, \mathrm{Fe}^{3+}$ & \\
\hline 711,3 & 1,7 & 28,1 & $\mathrm{FeOOH}, \mathrm{Fe}^{3+}$ & \\
\hline 712,7 & 2,0 & 24,3 & \multirow{2}{*}{$\begin{array}{c}\mathrm{Fe}_{3}\left(\mathrm{PO}_{4}\right)_{2}, \mathrm{FePO}_{4}, \\
\mathrm{sat}\left(\mathrm{Fe}^{2+}\right) \\
\mathrm{Fe}^{2+} \& \mathrm{Fe}^{3+}\end{array}$} & \multirow[b]{2}{*}[44,45]{} \\
\hline 714,4 & 2,2 & 24,3 & & \\
\hline
\end{tabular}

After EP50 in the studied surface layer there are over two times less metallic iron and about one-and-a-half times less iron oxides and about two times more iron hydroxides than in the steel surface layer after EP 1000. About two times more sulfates and phosphates of iron were detected in the surface layer after EP50 than those after EP1000.
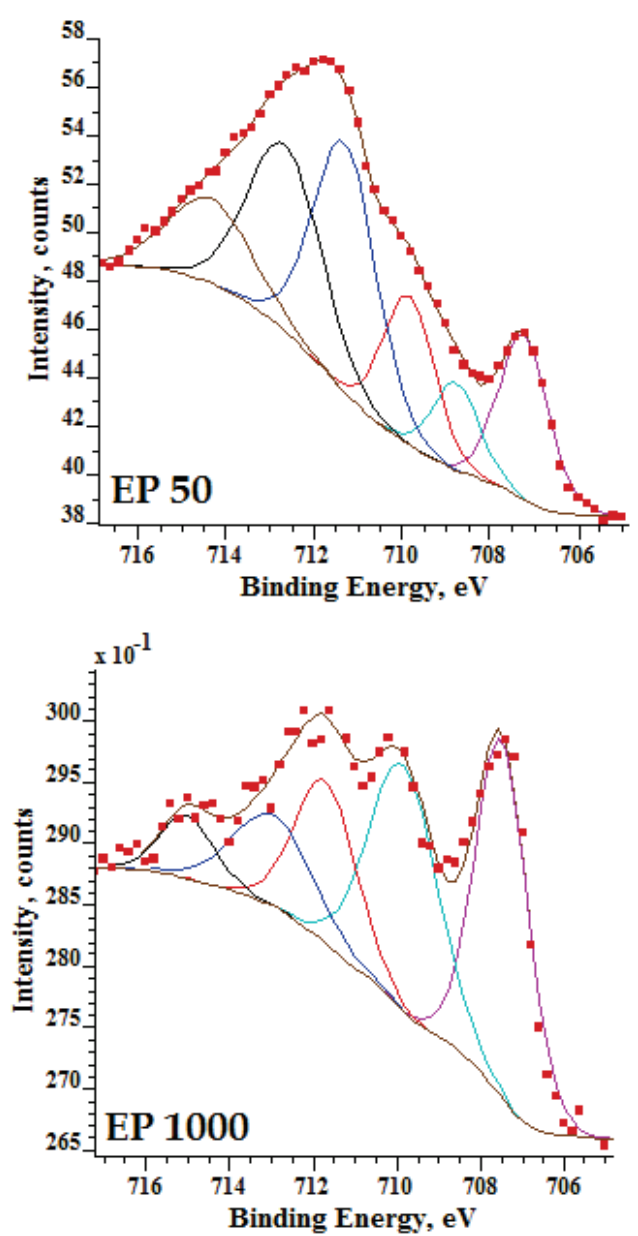

Figure 16 Fitting Fe 2p3/2 for EP 50 \& EP1000 data (electrolyte: pure $\mathrm{H}_{3} \mathrm{PO}_{4}$ )

Table 14 Results of fitting Fe 2p3/2 for EP 1000 data (electrolyte: pure $\left.\mathrm{H}_{3} \mathrm{PO}_{4}\right)$

\begin{tabular}{|c|c|c|c|c|}
\hline \\
\hline $\mathrm{BE} / \mathrm{eV}$ & FWHM & $\begin{array}{c}\text { Fe } 2 p / \\
\text { at } \%\end{array}$ & Iron compounds & Ref. \\
\hline 707.5 & 1.5 & 33.4 & $\mathrm{Fe}^{0}$ & \multirow{3}{*}[36,41,42]{} \\
\hline 709.9 & 2.0 & 30.3 & $\mathrm{FeO}, \mathrm{Fe}^{2+}$ & \\
\hline 711.7 & 1.7 & 17.5 & $\mathrm{FeOOH}, \mathrm{Fe}^{3+}$ & \\
\hline 713.0 & 2.2 & 12.8 & \multirow{2}{*}{$\begin{array}{c}\mathrm{Fe}_{3}\left(\mathrm{PO}_{4}\right)_{2}, \mathrm{FePO}_{4} \\
\mathrm{sat}\left(\mathrm{Fe}^{2+}\right) \\
\mathrm{Fe}^{2+} \& \mathrm{Fe}^{3+} \\
\end{array}$} & \multirow[b]{2}{*}[44,45]{} \\
\hline 715.0 & 2.2 & 6.0 & & \\
\hline
\end{tabular}

Table 15 Results of fitting Cr 2p3/2 for EP 50 data (electrolyte: pure $\mathrm{H}_{3} \mathrm{PO}_{4}$ )

\begin{tabular}{|c|c|c|c|c|}
\hline \multicolumn{5}{|c|}{$\left.\mathrm{H}_{3} \mathrm{PU}_{4}\right)$} \\
\hline $\mathrm{BE} / \mathrm{eV}$ & FWHM & $\begin{array}{c}\mathrm{Cr} 2 \mathrm{p} / \\
\text { at } \%\end{array}$ & Chromium compounds & Ref. \\
\hline 574,4 & 1,4 & 11,0 & $\mathrm{Cr}^{0}$ & [36] \\
\hline 575,7 & 1,1 & 15,8 & \multirow{5}{*}{$\begin{array}{l}\mathrm{Cr}_{2} \mathrm{O}_{3} \\
\left(\mathrm{Cr}^{3+}\right)\end{array}$} & \multirow{8}{*}{ 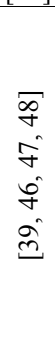 } \\
\hline 576,5 & 1,1 & 15,4 & & \\
\hline 577,5 & 1,0 & 8,4 & & \\
\hline 578,5 & 1,0 & 3,5 & & \\
\hline 578,9 & 1,0 & 2,2 & & \\
\hline 577,3 & 1,5 & 22,9 & $\begin{array}{c}\mathrm{CrOOH}, \mathrm{Cr}(\mathrm{OH})_{3} \\
\left(\mathrm{Cr}^{3+}\right)\end{array}$ & \\
\hline 578,0 & 1,8 & 13,2 & $\mathrm{Cr}_{2}\left(\mathrm{SO}_{4}\right)_{3}, \mathrm{CrPO}_{4},\left(\mathrm{Cr}^{3+}\right)$ & \\
\hline 579,5 & 1,6 & 7,6 & $\left(\mathrm{CrO}_{4}\right)^{2}, \mathrm{Cr}^{6+}$ & \\
\hline
\end{tabular}


Table 16 Results of fitting Cr 2p3/2 for EP 1000 data (electrolyte: pure $\left.\mathrm{H}_{3} \mathrm{PO}_{4}\right)$

\begin{tabular}{|c|c|c|c|c|}
\hline \\
\hline $\mathrm{BE} / \mathrm{eV}$ & FWHM & $\begin{array}{c}\mathrm{Cr} 2 \mathrm{p} / \\
\mathrm{at} \%\end{array}$ & Chromium compounds & Ref. \\
\hline 574,4 & 0,8 & 5,6 & $\mathrm{Cr}^{0}$ & {$[36]$} \\
\hline 575,7 & 1,1 & 11,1 & \multirow{5}{*}{$\begin{array}{l}\mathrm{Cr}_{2} \mathrm{O}_{3} \\
\left(\mathrm{Cr}^{3+}\right)\end{array}$} & \multirow{8}{*}{$\begin{array}{l}\frac{\infty}{+} \\
\tilde{+} \\
\dot{\sigma} \\
\dot{+} \\
\hat{m}\end{array}$} \\
\hline 576,5 & 0,9 & 10,7 & & \\
\hline 577,5 & 0,9 & 5,9 & & \\
\hline 578,5 & 0,9 & 2,4 & & \\
\hline 578,8 & 0,9 & 1,6 & & \\
\hline 577,1 & 1,6 & 23,0 & $\begin{array}{c}\mathrm{CrOOH}, \mathrm{Cr}(\mathrm{OH})_{3} \\
\left(\mathrm{Cr}^{3+}\right)\end{array}$ & \\
\hline 578,0 & 1,3 & 29,1 & $\mathrm{Cr}_{2}\left(\mathrm{SO}_{4}\right)_{3}, \mathrm{CrPO}_{4},\left(\mathrm{Cr}^{3+}\right)$ & \\
\hline 579,5 & 1,1 & 10,6 & $\left(\mathrm{CrO}_{4}\right)^{2}, \mathrm{Cr}^{6+}$ & \\
\hline
\end{tabular}

In case of chromium analysis, about two times more metallic chromium as well as more than about one-and-ahalf chromium III oxides were detected in the studied surface layer after EP50 than in those after EP1000. After EP 1000 there was observed in the passive layer over two times more sulfates and phosphates of chromium and about 1.4 atomic percent more compounds on the sixth stage of oxidation than in those after EP50.

\section{Discussion}

In that paper a thorough analysis was carried out concerning the surface layers of AISI 316L stainless steel after electrochemical polishing in different electrolytes based on phosphoric acid $\left(\mathrm{H}_{3} \mathrm{PO}_{4}\right)$ and sulfuric acid $\left(\mathrm{H}_{2} \mathrm{SO}_{4}\right)$ under different concentrations. It was noted that after most of electrochemical treatments the amount of iron was always less after EP1000 than that after EP50. The maximum amount of iron was observed in the steel surface film without any treatment (as received), and the minimum amount - after electrochemical treatment EP1000 under polishing in $60 \mathrm{vol} \% \mathrm{H}_{3} \mathrm{PO}_{4}$ and $40 \mathrm{vol} \%$ $\mathrm{H}_{2} \mathrm{SO}_{4}$ solution. In case of the chromium content, the maximum was noted for EP50 and the minimum for EP1000 in the same electrolyte $\left(60 \mathrm{vol} \% \mathrm{H}_{3} \mathrm{PO}_{4}\right.$ and 40 vol $\% \mathrm{H}_{2} \mathrm{SO}_{4}$ ). The maximum amount of molybdenum was noted for EP1000 in 40 vol $\% \mathrm{H}_{3} \mathrm{PO}_{4}$ and $60 \mathrm{vol} \% \mathrm{H}_{2} \mathrm{SO}_{4}$ electrolyte and the minimum for EP1000 (60 vol\% $\mathrm{H}_{3} \mathrm{PO}_{4}$ and $\left.40 \mathrm{vol} \% \mathrm{H}_{2} \mathrm{SO}_{4}\right)$. In case of pitting resistance coefficient, the Authors propose their own formula, i.e. $(\mathrm{Cr}+3.3 \cdot \mathrm{Mo}) / \mathrm{Fe}$, which is the highest for EP1000 treatment in $40 \quad$ vol\% $\quad \mathrm{H}_{3} \mathrm{PO}_{4}$ and 60 vol\% $\mathrm{H}_{2} \mathrm{SO}_{4}$ solution, and after electropolishing in pure phosphoric acid at $1000 \mathrm{~A} / \mathrm{dm}^{2}$. The other aspect of surface layer composition is the amount of chromium compounds on the sixth stage of oxidation which, if too high left, can sensitize the human body.

The lowest amount of chromium on the sixth stage of oxidation, 1,6 at $\%$ was detected after a standard electrochemical polishing EP50 in 60 vol\% $\mathrm{H}_{3} \mathrm{PO}_{4}$ and 40 vol $\% \mathrm{H}_{2} \mathrm{SO}_{4}$ solution, and the maximum $(23,2$ at $\%)$ was found for treatment in the same electrolyte but with the high current density $\left(1000 \mathrm{~A} / \mathrm{dm}^{2}\right)$. In pure phosphoric acid at 50 and $1000 \mathrm{~A} / \mathrm{dm}^{2}$ there was also noted a high amount of chromium VI compounds with 7,6 and 10,6 at $\%$, respectively. The carcinogenic nickel was not detected only after the treatment at EP1000 in $60 \mathrm{vol} \%$ $\mathrm{H}_{3} \mathrm{PO}_{4}$ and 40 vol $\% \mathrm{H}_{2} \mathrm{SO}_{4}$ solution. It is worth noting that the maximum of that element was observed on the steel sample surface without any treatment (as received).
In order to determine a dimensionless coefficient characterizing the amount of nickel in the surface layer, the Authors propose $100 \cdot[\mathrm{Ni} /(\mathrm{Fe}+\mathrm{Cr}+\mathrm{Mo})]$ coefficient. On the basis of this formula it follows that the maximum number of that coefficient $(6,5)$ is ascribed to the EP50 treatment in pure phosphoric acid, and then in descending order it is: 5,0 for EP50 (60 vol\% $\mathrm{H}_{3} \mathrm{PO}_{4}$ and $40 \mathrm{vol} \%$ $\mathrm{H}_{2} \mathrm{SO}_{4}$ ); 3,5 for EP1000 (pure $\mathrm{H}_{3} \mathrm{PO}_{4}$ ); 3,0 for EP 50 (40 vol $\% \mathrm{H}_{3} \mathrm{PO}_{4}$ and 60 vol $\left.\% \mathrm{H}_{2} \mathrm{SO}_{4}\right)$; and 2,2 for EP 1000 $\left(40 \mathrm{vol} \% \mathrm{H}_{3} \mathrm{PO}_{4}\right.$ and $60 \mathrm{vol} \% \mathrm{H}_{2} \mathrm{SO}_{4}$ ). On the basis of obtained data, it is possible to tailor the surface layer properties to particular applications. In view of conditions which biomaterials must fulfill, this is the biocompatibility. Following that way, the most advantageous is to have minimum amount or absence of carcinogenic nickel and minimum of chromium on the sixth stage of oxidation compounds as well high corrosion resistance. This condition is met by inter alia EP1000 treatment in $60 \mathrm{vol} \% \mathrm{H}_{3} \mathrm{PO}_{4}$ and $40 \quad \mathrm{vol} \% \mathrm{H}_{2} \mathrm{SO}_{4}$ solution, where there is no nickel detected in the passive layer, but the amount of chromium VI (sensitizing) is the highest. The other treatment which can be classified to polishing biomaterials is a standard electrochemical polishing, i.e. EP50 in $60 \mathrm{vol} \% \mathrm{H}_{3} \mathrm{PO}_{4}$ and $40 \mathrm{vol} \%$ $\mathrm{H}_{2} \mathrm{SO}_{4}$ solution. Other conditions for electrochemical treatments can be used for materials not implanted in the human body after which a good corrosion resistance is obtained, here high $(\mathrm{Cr}+3,3 \cdot \mathrm{Mo}) / \mathrm{Fe}$ corrosion coefficient. The electrochemical polishing EP1000 in pure phosphoric acid as well as EP1000 in 40 vol\% $\mathrm{H}_{3} \mathrm{PO}_{4}$ and $60 \mathrm{vol} \% \mathrm{H}_{2} \mathrm{SO}_{4}$ electrolyte may be considered for the treatments, where the corrosion coefficients equal 3,3 and 3,6 , respectively.

\section{Conclusion}

The following conclusions may be formulated from these HDEP studies of AISI 316L stainless steel:

(1) the electrochemical polishing using high current density $\left(1000 \mathrm{~A} / \mathrm{dm}^{2}\right)$ results in the formation of a passive layer of the chemical composition more different than that obtained after a standard electrochemical treatment $\left(50 \mathrm{~A} / \mathrm{dm}^{2}\right)$,

(2) the phosphoric-acid-to-sulfuric-acid volume ratio of electrolyte has an influence on the chemical composition of the passive film formed after electrochemical polishing,

(3) the highest amount of corrosion coefficient $[(\mathrm{Cr}+$ $3,3 \cdot \mathrm{Mo}) / \mathrm{Fe}=3,6]$ has been noted after EP1000 in 40 vol $\% \mathrm{H}_{3} \mathrm{PO}_{4}$ and 60 vol $\% \mathrm{H}_{2} \mathrm{SO}_{4}$ solution,

(4) the lowest amount of corrosion coefficient $[(\mathrm{Cr}+$ $3,3 \cdot \mathrm{Mo}) / \mathrm{Fe}=1,5]$ has been found after EP50 in pure concentrated $\mathrm{H}_{3} \mathrm{PO}_{4}$,

(5) after electrochemical polishing EP1000 in $60 \mathrm{vol} \%$ $\mathrm{H}_{3} \mathrm{PO}_{4}$ and 40 vol\% $\mathrm{H}_{2} \mathrm{SO}_{4}$ solution there was not recorded any nickel signal in XPS measurement of surface layer,

(6) the minimum amount of nickel compounds in the surface film was detected after EP1000 in 40 vol\% $\mathrm{H}_{3} \mathrm{PO}_{4}$ and 60 vol\% $\quad \mathrm{H}_{2} \mathrm{SO}_{4}$ solution; for that treatment the $100 \cdot[\mathrm{Ni} /(\mathrm{Fe}+\mathrm{Cr}+\mathrm{Mo})]$ coefficient equals 2,2, 
(7) the maximum amount of nickel compounds in surface film was detected after EP50 in pure $\mathrm{H}_{3} \mathrm{PO}_{4}$; for that treatment the $100 \cdot[\mathrm{Ni} /(\mathrm{Fe}+\mathrm{Cr}+\mathrm{Mo})]$ coefficient equals 6,1 ,

(8) the minimum amount of chromium on the sixth oxidation stage as compounds in the surface film was detected after EP50 in 60 vol\% $\mathrm{H}_{3} \mathrm{PO}_{4}$ and $40 \mathrm{vol} \%$ $\mathrm{H}_{2} \mathrm{SO}_{4}$ solution; it was equal to 1,6 at $\%$ of total chromium in the surface layer,

(9) the maximum amount of chromium on the sixth oxidation stage as compounds in the surface film was detected after EP1000 in $60 \mathrm{vol} \% \mathrm{H}_{3} \mathrm{PO}_{4}$ and $40 \mathrm{vol} \%$ $\mathrm{H}_{2} \mathrm{SO}_{4}$ solution; it was equal to 23,2 at $\%$ of total chromium in the surface layer,

(10) the electrochemical treatments EP50 and EP1000 in $40 \mathrm{vol} \% \mathrm{H}_{3} \mathrm{PO}_{4}$ and $60 \mathrm{vol} \% \mathrm{H}_{2} \mathrm{SO}_{4}$ solution as well as EP50 in $60 \mathrm{vol} \% \mathrm{H}_{3} \mathrm{PO}_{4}$ and $40 \mathrm{vol} \% \mathrm{H}_{2} \mathrm{SO}_{4}$ solution as electrochemical polishing operations may be advised for $316 \mathrm{~L}$ SS when used for implanted parts to the human body,

(11) passive layer formed on 316L SS after EP1000 treatment in pure phosphoric acid is advantageous and may be advised for parts not used for medical purposes,

(12) passive layer formed after EP1000 in 60 vol\% $\mathrm{H}_{3} \mathrm{PO}_{4}$ $\begin{array}{lllll}\text { and } & 40 & \mathrm{vol} \% & \mathrm{H}_{2} \mathrm{SO}_{4} & \text { solution has minimum }\end{array}$ carcinogenic nickel and maximum of chromium VI (sensitizing); this qualifies the steel surface for the use as a biomaterial, after prior earlier studies of the patient allergies.

\section{Acknowledgment}

The Berliner Luftcompany, especially Bogusław Lackowski, $\mathrm{PhD}$ is acknowledged for delivering samples for the studies. The Authors acknowledge Assoc. Prof. Gregor Mori DSc PhD of Montanuniversität Leoben, Austria, for providing bulk chemical composition of the AISI 316L austenitic stainless steel used in the studies.

\section{References}

[1] http://www.lenntech.com

[2] Rokosz, K.; Hryniewicz, T.; Valíček, J.; Harničárová, M.; Vyležík, M. Nanoindentation measurements of AISI 316L biomaterial samples after annual immersion in Ringer's solution followed by electrochemical polishing in a magnetic field). // PAK (Measurement Automatics Monitoring). 58, 5(2012), pp. 460-463.

[3] Rokosz, K. Electrochemical polishing of steel in a magnetic field (Polerowani eelektrochemiczne stali w polu magnetycznym), Monograph nr 219, Copyright by Koszalin University of Technology, Koszalin 2012, (211 pages)

[4] Hryniewicz, T.; Rokosz, K. Polarization Characteristics of Magnetoelectropolishing Stainless Steels. // Materials Chemistry and Physics. 122, 1(2010), pp. 169-174. DOl: 10.1016/j.matchemphys.2010.02.055

[5] Hryniewicz, T.; Rokicki, R.; Rokosz, K. Corrosion Characteristics of Medical Grade AISI 316L Stainless Steel Surface after Electropolishing in a Magnetic Field. // Corrosion - The Journal of Science and Engineering, Corrosion Science Section. 64, 8(2008), pp. 660-665. DOl: 10.5006/1.3279927
[6] Hryniewicz, T. Selected problems of electrochemical polishing, (in Polish), PhD Thesis, Copyright by ITBN PolitechnikaWrocławska, Wrocław, 1978.

[7] Hryniewicz, T.; Rokosz, K.; Rokicki, R. Electrochemical and XPS Studies of AISI 316L Stainless Steel after Electropolishing in a Magnetic Field. // Corrosion Science, 50, 9(2008), pp. 2676-2681. DOI: 10.1016/j.corsci.2008.06.048

[8] Rokosz, K.; Hryniewicz, T. Pitting corrosion resistance of AISI $316 \mathrm{~L}$ SS in Ringer's solution after magnetoelectrochemical polishing. // Corrosion - The Journal of Science and Engineering. 66, 3(2010), (11 pages), 035004-1...11.

[9] Hryniewicz, T.; Rokosz, K. Analysis of XPS results of AISI $316 \mathrm{~L}$ SS electropolished and magnetoelectropolished at varying conditions. // Surface and Coatings Technology. 204, 16-17(2010), pp. 2583-2592.

[10] Rokosz, K., XPS measurement of chemical composition of surface layer formed on austenitic AISI 316L SS after electrochemical polishing in magnetic field, PAK (Measurement Automatics Monitoring), 57(5) (2011) 563567. DOI: 10.1002/srin.201200046

[11] Rokosz, K.; Hryniewicz, T.; Raaen, S., Characterization of passive film formed on AISI 316L Stainless Steel after Magnetoelectropolishing in a Broad Range of Polarization Parameters. // Steel Research International. 83, 9(2012), pp. 910-918, DOI: 10.1002/srin.201200046

[12] Rokosz, K.; Raaen, S. XPS measurements of martensitic stainless steel $4 \mathrm{H} 13$ after the electrochemical polishing. // Autobusy - Technika, Eksploatacja, SystemyTransportowe. 5, (2011), pp. 1-10.

[13] Rokosz, K.; Hryniewicz, T.; Raaen, S. XPS measurements of 4H13 martensitic steel after electropolishing operation with electrolyte stirring. // PAK (Measurement Automatics Monitoring). 58, 6(2012), pp. 545-548

[14] Rokosz, K.; Hryniewicz, T.; Raaen, S. XPS measurements of martensitic stainless steel $4 \mathrm{H} 13$ after Magnetoelectropolishing. // Autobusy - Technika, Eksploatacja, SystemyTranspor-towe. 5, (2012), pp. 421428.

[15] Hryniewicz, T.; Konarski, P.; Rokosz, K.; Rokicki, R. SIMS analysis of hydrogen content in near surface layers of AISI 316L SS after electrolytic polishing under different conditions. // Surface \& Coatings Technology. 205, 1718(2011), pp. 4228-4236, DOI: 10.1016/j.surfcoat.2011.03.024

[16] Rokosz, K.; Hryniewicz, T. XPS measurements of LDX 2101 duplex steel surface after magnetoelectropolishing. // International Journal of Materials Research, (former: Zeitschriftfür Metallkunde), 104, 12(2013), pp. 1223-1232, http://www.ijmr.de/MK110984.

[17] http://www.northamericanstainless.com

[18] Faust, C. L. Electropolishing-Stainless Steel. // Metal Finishing. 80, 9(1982), pp. 89-93.

[19] Faust, C. L. Electropolishing-Stainless Steel. Part I. // Metal Finishing. 80, 7(1982), pp. 21-25.

[20] Faust, C. L. Electropolishing-Stainless Steel. Part II. // Metal Finishing. 81, 2(1983), pp. 53-56.

[21] Faust C.L., Electropolishing Carbon and Low Alloy Steel Part I. // Metal Finishing. 81, 2(1983), pp. 47-51.

[22] Hensel, K. B. Electropolishing. // Metal Finishing. 98, 1(2000), pp. 440-446. DOI: 10.1016/S0026-0576(00)80353-0

[23] Toma, Y.; Kodera, A.; Hiyama, H. Electrochemical polishing method and polishing method, US 2009/0095637 A1, 2009.

[24] Hryniewicz, T. Physico-chemical and Technological Foundations of Electropolishing Steels (in Polish), Wydawnictwo Uczelniane WSI, Koszalin, 1989 (161 pages).

[25] Hryniewicz, T. Surface and Coatings Technology (in Polish), Copyright by Koszalin University of Technology, Koszalin, 2004 (382 pages). 
[26] Hryniewicz, T. Surface Electrochemistry for Materials and Mechanical Engineering, Proc. of the Intern. Sci. Confer. "Challenges to Civil and Mechanical Engineering in 2000 and Beyond", vol. 2, ed. by R. Ciesielski, B. Ciszewski, J. Z. Gronostajski, H. Hawrylak, J. Kmita and S. Kobielak, Wrocław, 1997, pp. 515-524.

[27] Hryniewicz, T. Conditions for Effective Electropolishing of Sculptured Surfaces, Proc. of the $1^{\text {st }}$ Intern. Confer. on Machining and Measurements of Sculptured Surfaces, (ed. by Adam Ruszaj, IOS) 24-26 November, Kraków, Poland, G13, A75-76, 1997, pp. 331-340.

[28] Srinivasan, K.; Krishnan, K. S. R.; Mohan, S.; Krishnan R. M.; Kanagaraj, D. The Role of Phosphoric Acid in Electropolishing of Stainless Steel, $202^{\text {nd }}$ Meeting - Salt Lake City, UT, G3-Corrosion General Poster Session, 2002, p. 355 .

[29] Hocheng, H. Method and apparatus for electropolishing aided by ultrasonic energy means, US Patent 6315885 , 2001.

[30] Kao, P. S.; Hocheng, H. Optimization of electrochemical polishing of stainless steel by grey relational analysis. // Journal of Materials Processing Technology. 140, 13(2003), pp. 255-259.

[31] Chen, S. C.; Tu, G. C.; Huang, C. A. The electrochemical polishing behavior of porous austenitic stainless steel (AISI 316L) in phosphoric-sulfuric mixed acids. // Surface and Coatings Technology. 200, 7(2005), pp. 2065-2071. DOI: 10.1016/j.surfcoat.2005.06.008

[32] Zhao, H.; Humbeeck, J. V.; Sohier, J.; Scheerder, I. D. Electrochemical polishing of $316 \mathrm{~L}$ stainless steel slotted tube coronary stents: an investigation of material removal and surface roughness. // Progress in Biomedical Research. 8, 2(2003), pp. 70-81.

[33] Gellér, Z. E.; Albrecht, K.; Dobránszky, J. Electropolishing of coronary stents. // Materials Science Forum. 589, (2008), pp. 367-372. DOI: 10.4028/www.scientific.net/MSF.589.367

[34] Raval, A.; Choubey, A.; Engineer, C.; Kothwala, D. Development and assessment of 316LVM cardiovascular stents. // Materials Science and Engineering A. 386, 12(2004), pp. 331-343.

[35] Tomassi, P. (ed.) Chemical and electrochemical polishing (in Polish), in "Poradnik Galwanotechnika", ISBN 83-2042610-3, Wydawnictwo Naukowo-Techniczne, Warszawa, 2002, pp. 125-133.

[36] Crist, B. V. Handbook of monochromatic XPS spectra, The elements and native oxides, John Wiley \& Sons, Ltd., 2000.

[37] Nesbitt, H. W.; Banerjee, D. Interpretation of XPS Mn(2p) spectra of Mnoxyhydroxides and constraints on the mechanism of $\mathrm{MnO}_{2}$ precipitation. // American Mineralogist. 83, (1998), pp. 305-315.

[38] Flori, M.; Gruzza, B.; Bideux, B.; Monier, G.; RobertGoumet, C. A study of steel surface contamination by XPS electron spectroscopy. // Annals of Faculty Engineering Hunedoara - Journal of Engineering. 5, 1(2007), pp. 165170.

[39] Biesinger, M. C.; Brown, C.; Mycroft, J. R.; Davidson, R. D.; McIntyre, N. S. X-ray photoelectron spectroscopy studies of chromium compounds. // Surface and Interface Analysis. 36, 12(2004), pp. 1550-1563. DOl: 10.1002/sia.1983

[40] Santonen, T.; Stockmann-Juvala, H.; Zitting, A. Review on toxicity of stainless steel, Finnish Institute of Occupational Health, ISBN 978-952-261-039-3, 2010, (87 pages).

[41] Grosvenor, A. P.; Kobe, B. A.; Biesinger, M. C.; McIntyre N. S. Investigation of multiplet splitting of Fe $2 p$ XPS spectra and bonding in iron compounds. // Surface and Interface Analysis. 36, 12(2004), pp. 1564-1574. DOI: 10.1002/sia.1984
[42] Tauson, V. L.; Kravtsova, R. G.; Grebenshchikova, V. I.; Lustenberg, E. E.; Lipko, S. V. Surface typochemistry of hydrothermal pyrite: Electron spectroscopic and scanning probe microscopic data. I. Synthetic pyrite. // Geochemistry International. 48, 6(2010), pp. 565-577.

[43] Mazumder, M. K.; Lindquist, D. A.; Tennal, K. B. Electronic Surface Structures of Coal and Mineral Particles, Final Report, Grant ID: DE-FG22-96PC9.62-02, University of Arkansas at Little Rock, 2001.

[44] Wang, Y.; Sherwood, P. M. A. Iron (III) Phosphate (FePO4) by XPS. // Surface Science Spectra. 9, 1-4(2002), pp. 99-105.

[45] Wang, Y.; Asunskis, D. J.; Sherwood, P. M. A. Iron (II) Phosphate $\mathrm{Fe}_{3}\left(\mathrm{PO}_{4}\right)_{2}$ by XPS. // Surface Science Spectra. 9, 1-4(2002), pp. 91-98.

[46] Shahryari, A.; Omanovic, S.; Szpunar, J. A. Electrochemical formation of highly pitting resistant passive films on a biomedical grade 316LVM stainless steel surface. // Materials Science and Engineering C. 28, 56(2008), pp. 94-106.

[47] Kish, J. R.; Ives, M. B.; Rodda, J. R. Anodic behaviour of stainless steel S43000 in concentrated solutions of sulfuric acid. // Corrosion Science. 45, 7(2003), pp. 1571-1594. DOI: 10.1016/S0010-938X(02)00232-9

[48] Daulton, T. D.; Little, B. J. Determination of chromium valence over the range $\mathrm{Cr}(0)-\mathrm{Cr}(\mathrm{VI})$ by electron energy loss spectroscopy. // Ultramicroscopy. 106, (2006), pp. 561-573. DOI: 10.1016/j.ultramic.2006.02.005

\section{Authors' addresses}

\section{Krzysztof Rokosz \\ Tadeusz, Hryniewicz \\ Stawomir Rzadkiewic}

Division of Surface Electrochemistry and Engineering

Faculty of Mechanical Engineering,

Koszalin University of Technology

Racławicka 15-17,

PL 75-620 Koszalin, Poland

E-mail: rokosz@tu.koszalin.pl

E-mail: Tadeusz.Hryniewicz@tu.koszalin.pl

\section{Steiner Raaen}

Department of Physics

Norwegian University of Science and Technology (NTNU)

Realfagbygget E3-124 Høgskoleringen 5,

NO 7491 Trondheim, Norway

E-mail: steinar.raaen@ntnu.no 